\title{
Modeling vegetation and wind erosion \\ from a millet field and from a rangeland: two Sahelian case studies
}

\author{
Caroline PIERRE ${ }^{1,2}$, Laurent KERGOAT ${ }^{1}$, Gilles BERGAMETTI ${ }^{2}$, Éric MOUGIN ${ }^{1}$, Christian BARON ${ }^{3}$, \\ Amadou ABDOURHAMANE TOURE ${ }^{4}$, Jean-Louis RAJOT ${ }^{2,5}$, Pierre HIERNAUX', Béatrice MARTICORENA ${ }^{2}$, \\ Claire DELON ${ }^{6}$
}

${ }^{1}$ Géosciences Environnement Toulouse (GET),

CNRS/IRD/Université de Toulouse

14 Avenue Edouard Belin, 31400 Toulouse, France

laurent.kergoat@get.obs-mip.fr

eric.mougin@get.obs-mip.fr

pierre.hiernaux@get.obs-mip.fr

${ }^{2}$ Laboratoire Interuniversitaire des Systèmes Atmosphériques (LISA),

Universités Paris Est Créteil \& Paris Diderot, UMR CNRS 7583

61 Avenue du Général de Gaulle, 94000 Créteil, France

caroline.pierre@lisa.u-pec.fr (corresponding author, phone number: +33 1451715 79)

gilles.bergametti@lisa.u-pec.fr

beatrice.marticorena@lisa.u-pec.fr

${ }^{3}$ Centre de coopération Internationale en Recherche Agronomique pour le Développement (CIRAD)

500 Rue Jean François Breton, 34093 Montpellier Cedex 5, France

christian.baron@cirad.fr

${ }^{4}$ Université Abdou Moumouni, Jeune Equipe Associée à l'IRD, Anthropisation et Dynamique Eolienne (JEAI ADE), Département de Géologie, BP 10662 Niamey, Niger

doudu2000@yahoo.fr

${ }^{5}$ Institut d'Ecologie et des Sciences de l'Environnement (IEES-Paris), UMR IRD 242

Institut des Régions Arides (IRA), 4119, Médenine, Tunisia

jeanlouis.rajot@ird.fr

${ }^{6}$ Laboratoire d'Aérologie (LA)

14 Avenue Edouard Belin, 31400 Toulouse, France

claire.delon@aero.obs-mip.fr 


\begin{abstract}
Quantifying wind erosion and dust emissions in the semi-arid Sahel remains challenging because of the large seasonal and interannual dynamics of surface properties. The increasing conversion of rangelands into croplands raises issues for quantifying wind erosion over these two contrasted surfaces. Whereas wind erosion models have been so far applied to these two surface types separately, this study proposes a common modeling approach to represent the horizontal flux from Sahelian rangelands and croplands. Pair simulations of both typical Sahelian land surface types investigate the horizontal flux due to wind erosion over a 3-year period for two instrumented sites in Mali and Niger. Two different vegetation models simulate the specific phenology and growth of a rangeland grass and a millet crop. These models also account for the local cropping and pastoral practices. Compared to field measurements, the vegetation cover is satisfyingly simulated by the models, especially the strong seasonal dynamics. Specific parameterizations of the aerodynamic surface roughness length $\left(Z_{0}\right)$ as a function of vegetation variables are established using measurements from the two sites. The simulated horizontal flux turns out to be higher for a cropland than for a rangeland by approximately a factor 1.5, implying that increasing Sahelian cropped areas would increase dust emissions from the Sahel. This difference is mainly due to the time shift between grass and millet growth: the latter starts growing about 2 to 3 weeks later than annual grass. The amount of dry vegetation remaining during late dry season is also important for Sahelian wind erosion.
\end{abstract}

Keywords: wind erosion, Sahel, modeling, cropland, rangeland.

\title{
Highlights:
}

Sediment horizontal fluxes from a cropland and a rangeland in the Sahel are simulated Simulated vegetation and horizontal fluxes are in good agreement with measurements Horizontal mass flux is greater for cropland than rangeland by about a factor 1.5 


\section{Introduction}

Dust represents about $40 \%$ of the total amount of aerosols injected each year into the atmosphere

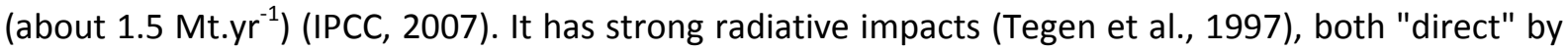
absorption and scattering of the solar and telluric radiations, and "indirect" when acting as cloud condensation nuclei (Haywood and Boucher, 2000). When deposited, dust can provide significant amounts of nutrients such as phosphorus and iron to remote oligotrophic oceanic areas (Jickells et al., 2005) or like phosphorus and potassium in continental environments (Swap et al., 1992; Hermann et al., 2010; Breuning-Madsen et al., 2015). In the semi-arid dust source regions, wind erosion can also decrease soil fertility of already poor soils (Lyles and Allison, 1976; Bielders et al., 2002), and damage crops through abrasion (Sterk, 2003).

At a global scale, the link between human activities and dust emissions - which result from wind erosion - is now recognized (Boucher et al., 2013). Especially, changes in land use influence dust emissions in populated semi-arid areas like the Sahel, where the number of inhabitants has more than doubled over the past 50 years. Meanwhile, according to many authors, Sahelian dust emissions increased during the early $20^{\text {th }}$ century and started decreasing from the late 1980's on (Moulin and Chiapello, 2006; Foltz and McPhaden 2008; Mahowald et al. 2010; Cowie et al, 2013; Chin et al, 2014; Doherty et al, 2014; Ridley et al, 2014). Recently, Stanelle et al. (2014) inferred from simulations that dust emissions from the agricultural areas of Northern Africa (including the Sahel) had increased from $2.8 \mathrm{Tg} . \mathrm{yr}^{-1}$ in 1880 to $8 \mathrm{Tg} . \mathrm{yr}^{-1}$ today. At a quasi-continental scale, Mulitza et al. (2010) hypothesized that the sudden increase in dust deposition off the West African coast about two centuries ago was linked to the onset of commercial agriculture in the Sahel. However, the relative roles played by climate change and human activities on Sahelian dust emissions are still debated, and no precise quantification of the dust emissions from this region is available (Tegen and Fung, 1995; Tegen et al., 2004; Mahowald et al., 2004). At a more local scale, studies based on field measurements performed in the Sahel have provided estimates of wind erosion in croplands (Bielders et al., 2001a; Sterk, 2003; Bielders et al., 2004), and rangelands (Tidjani et al., 2009). Several studies have suggested that wind erosion was significantly increased by cropping (Rajot, 2001; Bielders et al, 2002; Ikazaki et al. 2011), but studies on traditionally-managed crop fields are still scarce (Bielders et al., 2001b; Abdourhamane Touré et al., 2011). In addition, cropping (Sterk, 2003) and pastoral practices (Tidjani et al., 2009) can modulate wind erosion.

Until now, wind erosion modeling approaches have been developed for croplands and rangelands separately (Li et al., 2014). However, a common approach would help estimating wind erosion on these typical Sahelian surfaces, and their differences in terms of amounts and temporal dynamics. Another issue consists in representing the impacts of pastoral and cropping practices on wind erosion. The objective of this study is to model the horizontal fluxes of aeolian sediment of Sahelian croplands and rangelands with consistent modeling tools, and to discuss the differences of the simulated fluxes between these two surface types. Section 2 describes the data and the models development and setup. Results of the simulations are shown and evaluated in section 3 and further discussed in section 4. 


\section{Materials and Methods}

\subsection{Study sites and data}

The Sahel is characterized by a short rainy season lasting from approximately June to October, and a long dry season during the rest of the year (Lebel and Ali, 2009). Annual precipitation ranges fom about 100 to $600 \mathrm{~mm}$, allowing the growth of seasonal vegetation. Most of this rain is provided by a few mesoscale convective events, commonly accompanied by strong winds caused by systems outflows. The duration of these gusts ranges from a few minutes to more than one hour. Although the monsoon wind blows from South-West during the rainy season, the convective outflows are most often easterly winds, because convection mixes the African Easterly Jet down to the surface (Guichard et al., 2009). During the dry season, the Harmattan wind blows from North-East, while most plants wilt and progressively degrade. The main Sahelian land use is cultivation, usually with an alternance of cropping and fallowing periods over several years (e.g. Hiernaux and Turner, 2002), and grazing in the rangelands. After harvest, fields are open to grazing too.

Ideally, experimental sites would provide a full set of wind erosion measurements, meteorological data and soil description for pairs of cropped / non-cropped plots. Yet, experimental sites where both vegetation characteristics and wind erosion horizontal fluxes have been monitored are scarce in the Sahel, and no paired-experiment (monitoring vegetation and wind erosion over a cropland and a rangeland in the same area) has been documented so far. Given these constraints, two sites where at least some of these data were acquired have been selected (Table 1).

The first site is the Agoufou rangeland $\left(15.3^{\circ} \mathrm{N}, 1.5^{\circ} \mathrm{W}\right)$, a study site of about $1 \mathrm{~km}^{2}$ located in the Gourma area in Mali (e.g. Mougin et al., 2009). Agoufou is located in a typical pastoral Sahel area with annual rainfall averaging $350 \mathrm{~mm}$. The dominant land use is extensive grazing. Numerous measurements were performed at this site during the AMMA campaign (Multidisciplinary Analysis of the African Monsoon): meteorological variables from a station and a rain gauge (wind speed, rain amount, temperature, and solar radiation), soil texture, and soil moisture at the same location. Wind speed has been measured at $3.5 \mathrm{~m}$ height using a cup anemometer. Wind data provided by a 3D sonic anemometer were available during part of this period. Grass measurements have been performed along $1 \mathrm{~km}$ lines at about 15 dates each year of 2006-2008, and livestock observations have been collected at the nearby $(2.5 \mathrm{~km}$ ) permanent pond in 2010-2011 (Diawara, 2015). For this study, years 2006 to 2008 are retained because of their good data sampling and their contrasted rainfall conditions.

The second site is a rectangular traditionally-managed millet field (about $100 \mathrm{~m}$ by $150 \mathrm{~m}$ ) located in the Fakara region in Niger, in the vicinity of the village of Banizoumbou $\left(13.5^{\circ} \mathrm{N}, 2.7^{\circ} \mathrm{E}\right)$. This site is fairly representative of agropastoral Sahel and receives $500 \mathrm{~mm}$ of annual rain on average. The millet field is embedded in a typical crop/fallow/rangeland mosaic, where fields are protected from grazing during the rainy season and open to grazing during the dry season. On this site, meteorological data (wind speed, wind direction, rain amount, air temperature), millet height during growth, crop residues cover fraction, and horizontal fluxes have been monitored from 2006 to 2008 (Abdourhamane Touré et al., 2011). Wind speed has been monitored at 4 heights $(0.35,0.70,1.20$, and $2.50 \mathrm{~m}$ ). Solar radiation was not monitored at Banizoumbou but was provided by the Atmospheric Radiation Measurement (ARM) Mobile Facility in Niamey for year 2006. No measurements being available for 2007 and 2008, the 2006 measurements are used for the 3 years of simulation. This may not impact significantly the simulations since plant growth in the Sahel is 
mainly limited by precipitation. Horizontal fluxes have been measured with BSNE sand traps (Fryrear, 1986) on a daily basis. Pierre et al. (2014a) performed horizontal flux simulations for this site.

The two study sites have sandy soils that are typical of the Sahelian area. Information on the dry grain size distribution is available only at Banizoumbou, indicating a silt and clay proportion of about $5 \%$ together (Sabre et al., 1997). At Agoufou, the sand content of the top soil layer is about 95\% (De Rosnay et al., 2009, Table 2), thus indicating the dominance of sand, like at Banizoumbou. Numerical tests (not shown) showed that for such fine sand the impact of a precise grain size distribution on the simulated horizontal flux is very low. It was not taken into account in this study.

Table 1: Available datasets and their characteristics (temporal coverage, time resolution) for Agoufou and Banizoumbou ( $U$ : wind velocity; $u *$ : wind friction velocity)

\begin{tabular}{|c|c|c|}
\hline & Agoufou (Mali) & Banizoumbou (Niger) \\
\hline \multirow{7}{*}{ wind } & $\mathrm{U}$ at $3.5 \mathrm{~m}$ & $\mathrm{U}$ at 4 heights $(0.35,0.70,1.20,2.50 \mathrm{~m})$ \\
\hline & 2006 to 2008 & 2006 to 2008 \\
\hline & 15 minutes & 5 minutes \\
\hline & & \\
\hline & $u^{*}$ & wind direction \\
\hline & part of 2005, 2006, 2007 & 2006 to 2008 \\
\hline & 5 minutes & 5 minutes \\
\hline rain & \multirow{6}{*}{$\begin{array}{c}2006 \text { to } 2008 \\
15 \text { minutes }\end{array}$} & 2006 to 2008 \\
\hline air temperature & & 5 minutes \\
\hline & & \\
\hline \multirow[t]{2}{*}{ solar radiation } & & 2006 \\
\hline & & 15 minutes \\
\hline soil moisture & & No \\
\hline \multirow[t]{2}{*}{ vegetation } & grass mass 2006 to 2008 & millet height 2006 to 2008 \\
\hline & 43 dates & 39 dates during rainy season \\
\hline \multirow[t]{2}{*}{ horizontal flux } & No & 2006 to 2008 \\
\hline & & daily \\
\hline
\end{tabular}

\subsection{Modeling approach}

In order to estimate the respective wind erosion horizontal fluxes from a cropland and a rangeland under identical climatic and soil conditions, simulations are performed to represent the vegetation cycle of rangeland and millet over three years for each of the two selected sites. For that purpose, different models are used: a model describing the seasonal dynamics of the rangeland grass, a crop model simulating the millet growth cycle, and a wind erosion model. In other words, the two monitored cases of Agoufou rangeland and Banizoumbou millet field are simulated, as well as two additional cases (not monitored) of a millet field at Agoufou and a rangeland at Banizoumbou. Horizontal fluxes are simulated for both sites and both vegetation types. Combining the vegetation and wind erosion models requires parameterizing the seasonal dynamics of the surface properties, like the aerodynamic surface roughness length $\left(Z_{0}\right)$, as a function of vegetation characteristics. 


\subsection{Vegetation modeling}

Two vegetation growth models are used: the STEP model (Sahelian Transpiration Evaporation and Productivity model; Mougin et al., 1995; Tracol et al., 2006) for the rangeland grass, and the SarraH model (Système d'Analyse Régionale des Risques Agroclimatiques - Version 3.2; Dingkuhn et al., 2003) for millet crops. These models run on a daily time step and provide the vegetation mass and Leaf Area Index (LAI) over the whole annual cycle. The mass values are simulated for green vegetation, standing straws, and litter by both models. The STEP model has been specifically designed to simulate the growth of annual grass under Sahelian conditions, and it exhibits good skills over the Sahel when compared to satellite-based indices (Lo Seen et al., 1995; Jarlan et al., 2002; Pierre et al., 2011). The SarraH model has been widely tested and used for several millet breeds for Sahelian sites in Senegal, Mali and Niger (Baron et al., 2005; Kouressy et al., 2008; Traoré et al., 2011; Marteau et al., 2011). The main differences between these two models are the representation of the phenological stages during the vegetation cycle, and the mass partition between leaves, stems and grain, for millet. Recently, these two models have been extended to simulate the vegetation during the dry season, taking into account grazing and trampling by livestock (Delon et al., 2015), and cropping practices in millet fields (see Appendix).

To simulate grazing for the rangeland, livestock density is provided by field observations in 20102011 around the Agoufou pond (Diawara, 2015). In agreement with field observations, a lower soil fertility (and hence a lower light-use-efficiency parameter in the STEP simulations) is assumed for the rangeland in Banizoumbou compared to Agoufou. For millet simulations, grazing pressure is set at 5 TLU. $\mathrm{km}^{-2}$ (Tropical Livestock Unit), which is typical of moderately grazed areas in the Sahel (Hiernaux and Turner, 2002). Every year, the remaining standing millet straws are laid down into litter on January $1^{\text {st }}$ (hereafter referred to as field clearing), a date considered as typical according to local observations. The Banizoumbou experimental plot was been clean-weeded, as commonly done for millet in the Sahel, thus it is assumed that no weeds grow in millet fields. Consitently with local observations (Abdourhamane Touré et al., 2011), the millet sowing date is searched for by the crop model from June $7^{\text {th }}$ on, the same millet variety ("Haini Kirey") is represented for both sites, and a slight quantity of manure is applied in the case of Banizoumbou (see Schlecht et al., 2004), but none at Agoufou. This difference is expressed by a conversion efficiency parameter, which is used in the SararaH model to compute the dry matter produced by photosynthesis according to water stress and radiation, and takes into account the effect of manure. Its value is set to $4 \mathrm{~g} . \mathrm{MJ}^{-1}$ for Banizoumbou against 3.6 g.MJ ${ }^{-1}$ for Agoufou. Models are spun up in 2005 to provide dry season vegetation variables in early 2006.

During the dry season, only vegetation masses are computed by the SarraH model. Two additional values have to be derived from vegetation models outputs in order to simulate wind erosion, namely the erodible surface fraction $(E)$, i.e. the fraction of the surface on which wind erosion can occur, and the aerodynamic surface roughness length $\left(Z_{0}\right)$. Indeed, it has been shown for both rangeland and millet field that $Z_{0}$ adequately accounts for the role of the surface properties on the wind shear stress that controls wind erosion (Pierre et al., 2014a, b).

The vegetation cover fraction $\left(f_{c v}\right)$ is required to determine $E$ :

$E=1-f_{c v}$

For green grass, $\mathrm{f}_{\mathrm{cv}}$ is computed by the STEP model from the simulated green $\mathrm{LAI}_{\mathrm{g}}$ as follows: 
$f_{c v}=1-e^{-K \cdot L A I_{g}}$

with $\mathrm{K}=0.431$ (Mougin et al., 2014). For standing millet, the same parameterization is applied to the LAI simulated by the SarraH model, with $\mathrm{K}=0.45$ according to field trials. For grass straws and litter, the STEP model provides vegetation cover fraction based on the following parameterizations respectively:

$f_{c v}=\left(1-e^{-0.9 \cdot L A I_{t}}\right) \cdot \frac{L A I_{s}}{L A I_{t}}$

where $L A I_{t}$ (in $\mathrm{m}^{2} \cdot \mathrm{m}^{-2}$ ) is the total LAI (for green grass and straws) and LAI ${ }_{s}$ is the straws LAI, and:

$f_{c v}=0.05 \cdot \ln \left(1+\frac{B M_{l i t}}{28}\right)$

for litter, where $\mathrm{BM}_{\mathrm{lit}}$ is the litter mass (in g. $\mathrm{m}^{-2}$ ). Total grass cover fraction is the sum of the contributions of green grass, straws and litter.

Before field clearing, the millet cover fraction is the sum of the contribution of laying litter and standing straws. This latter contribution is estimated by Eq. (2), with LAI being computed as the product of the Specific Leaf Area (SLA) at harvest by the dry leaves mass, thus considering that stems have a negligible LAI. The millet cover fraction for litter is estimated by the regression proposed by Abdourhamane Touré et al. (2011, Figure 8):

$f_{c v}=\frac{\left(0.14 B M_{l i t}+0.23\right)}{100}$

with $\mathrm{BM}_{\text {lit }}$ the millet litter mass (in $\mathrm{g} \cdot \mathrm{m}^{-2}$ ). After field clearing, the cover fraction is only due to litter. According to preliminary work (not shown), millet height appeared to be a relevant variable to derive $Z_{0}$, while vegetation mass is the most relevant one to estimate $Z_{0}$ for grass (in agreement with Tidjani et al., 2009). In the simulations, millet height is estimated from the modeled phenological stages with a parameterization based on the millet heights measurements performed on the Banizoumbou field. According to these measurements, millet height follows two successive linear evolutions in time, with slopes corresponding to two distinct periods of the SarraH simulations: first, the vegetative growth from germination to flower initiation, and second, the reproductive growth from tiller elongation to grain filling. During grain drying (i.e. the last stage) millet height no longer increases. The following relations are obtained:

$\mathrm{H}=0.0076 \Delta \mathrm{j} \quad$ (first period)

$\mathrm{H}=0.0378 \Delta \mathrm{j}+\mathrm{H}_{\mathrm{c}} \quad$ (second period)

where $\mathrm{H}$ is the plant height (in $\mathrm{m}$ ) and is truncated to $2.3 \mathrm{~m}$ (according to Banizoumbou field observations), $\Delta \mathrm{j}$ is the number of days since the beginning of the considered period, and $\mathrm{H}_{\mathrm{c}}$ is the millet height at the last day of the first period, which ensures continuity. Millet height after harvest is estimated as the product of its maximum height (at harvest) by the ratio of stem mass at the considered date to stem mass at harvest. The clearing of the field being set on January $1^{\text {st }}$, the millet height becomes nil at that date, until the next rainy season. 


\subsection{Surface characteristics estimates}

$Z_{0}$ is first estimated from measurements on the two sites. Then, these measurements are used to establish relations between the $Z_{0}$ values and measured vegetation characteristics in order to determine parameterizations that can be used to derive $Z_{0}$ from the vegetation model outputs. The estimation of $Z_{0}$ is based on selected wind measurements assuming a logarithmic wind profile (Priestley, 1959):

$$
\mathrm{u} *=k \frac{U(z)}{\ln \left(\frac{z}{z_{0}}\right)}
$$

with $k$ the von Karman constant $(k=0.4), U$ the wind speed (in $\left.\mathrm{m}^{-1} \mathrm{~s}^{-1}\right), \mathrm{u} *$ the wind friction velocity (in $\left.\mathrm{m} . \mathrm{s}^{-1}\right), \mathrm{z}$ the height and $\mathrm{Z}_{0}$ the aerodynamic surface roughness length $\left(z\right.$ and $Z_{0}$ are in the same length unit). Because of the different experimental setups in the two sites, $Z_{0}$ values are estimated from friction velocity estimates at Agoufou and from wind profile measurements at Banizoumbou. A typical seasonal cycle of $Z_{0}$ is derived from the pluriannual measurements performed at both sites.

\section{Agoufou site:}

At Agoufou, wind velocity and wind friction velocity are used at 30-minute time resolution to retrieve $Z_{0}$ by solving Eq. (7). Wind friction velocity is derived from the sonic anemometer measurements following Walker (2005). The purpose being to describe a typical seasonal cycle for rangeland $Z_{0}$, years 2005, 2006 and 2007 are used. An instrumental drift has occurred after 2007 that prevent the derivation of $Z_{0}$ for 2008. A set of criteria proposed by Marticorena et al. (2006) is adapted to filter wind measurements.

To select the wind measurements performed in near-neutral conditions, only the data acquired between $6 \mathrm{am}$ and $8 \mathrm{am}$ and between $6 \mathrm{pm}$ and $8 \mathrm{pm}$ in local time, and leading to a Monin-Obukov length such as $|z / L|<0.02$ are retained. To discard the possible remaining free convection, only periods during which $U>1 \mathrm{~m} . \mathrm{s}^{-1}$ and $\mathrm{u}_{*}>0.2 \mathrm{~m} . \mathrm{s}^{-1}$ are retained. Outliers are removed by keeping only $\mathrm{u}_{*}<1 \mathrm{~m} . \mathrm{s}^{-1}$ and $\mathrm{Z}_{0}<0.12 \mathrm{~m}$, these limits being consistent with the $\mathrm{Z}_{0}$ values found for grass in the literature (e.g. Marticorena et al., 2006; Tidjani et al., 2009). Finally, $Z_{0}$ are estimated each year by a 30-days sliding median to overcome remaining data scarcity and to remove outliers.

From March to October (i.e. the period during which measurements are available), $Z_{0}$ values averaged over the 3 years show a decrease of $Z_{0}$ from March $(\sim 0.015 \mathrm{~m})$ to June $(\sim 0.007 \mathrm{~m})$, and a rapid growth from July to October $(\sim 0.050 \mathrm{~m}$ ) (Figure 1). These values are in agreement with the literature for this cover type, as reviewed by Marticorena et al. (2006, Table 7): Pasquill (1950) obtained a value of 0.030 to $0.070 \mathrm{~m}$ for 'long grass'. Similarly, $Z_{0}$ values for 'short grass' vary from $0.002 \mathrm{~m}$ (Deacon, 1953) to $0.011 \mathrm{~m}$ (Saugier and Ripley, 1978), depending on the authors. More recently, Tidjani et al. (2009) obtained a $Z_{0}$ value of $0.050 \mathrm{~m}$ at the peak of vegetation for a rangeland site located in southeastern Niger.

\section{Banizoumbou site:}

30-minute averaged values are used to retrieve $Z_{0}$ from linear regression of the wind profile described by Eq. (5). For that purpose, several criteria are also adapted from Marticorena et al. (2006). To select near neutral conditions, only wind speeds recorded between 6am and 8am and between $6 \mathrm{pm}$ and $8 \mathrm{pm}$ in local time are retained. In order to avoid free convection, regression is only 
calculated if wind speed at all heights is greater than $1 \mathrm{~m} \cdot \mathrm{s}^{-1}$, and the result of the regression is retained only if $u_{*}$ from the regression is greater than $0.2 \mathrm{~m} . \mathrm{s}^{-1}$. Additionally, the result of the regression is retained if the difference between measured and fitted wind velocities is lower than $5 \%$ at all heights. Finally, a last selection is made on wind direction to keep the values corresponding to the four corners of the field, i.e. to the maximal fetch of the measurements: values are retained in four angles of $12^{\circ}$ (field corners $+/-6^{\circ}$ ).

From January to the end of July, measurements from the 4 heights can be used. As millet reaches the lowest sensor around the beginning of the rainy season, only the 3 upper ones are used afterwards. Millet further reaches the second sensor at $0.7 \mathrm{~m}$ (in early August 2006 and 2007, around mid-July 2008), causing $Z_{0}$ values obtained after these dates to be less accurate.

The $Z_{0}$ estimates corresponding to millet heights up to $1 \mathrm{~m}$ (rather than $0.7 \mathrm{~m}$ like in Abourhamane Touré et al., 2011) are retained here, in order to capture the growing period in terms of roughness length time series and to allow high values to be used in the parametrizations. Erosion does not occur when millet is fully developped, so the accuracy of $Z_{0}$ is not critical at this period of the year. Finally, $Z_{0}$ is estimated for each year by a 30-days sliding median.

The resulting seasonal cycle of $Z_{0}$, averaged over the 3 years (Figure 1), reaches approximately 0.005 $\mathrm{m}$ in the late dry season (March to June). It increases from July on, until reaching about $0.020 \mathrm{~m}$ at the beginning of August. Since millet stems remain standing until field clearing on January $1^{\text {st }}$, no $Z_{0}$ values are derived from about mid-July or August - depending on the year - to the end of December.

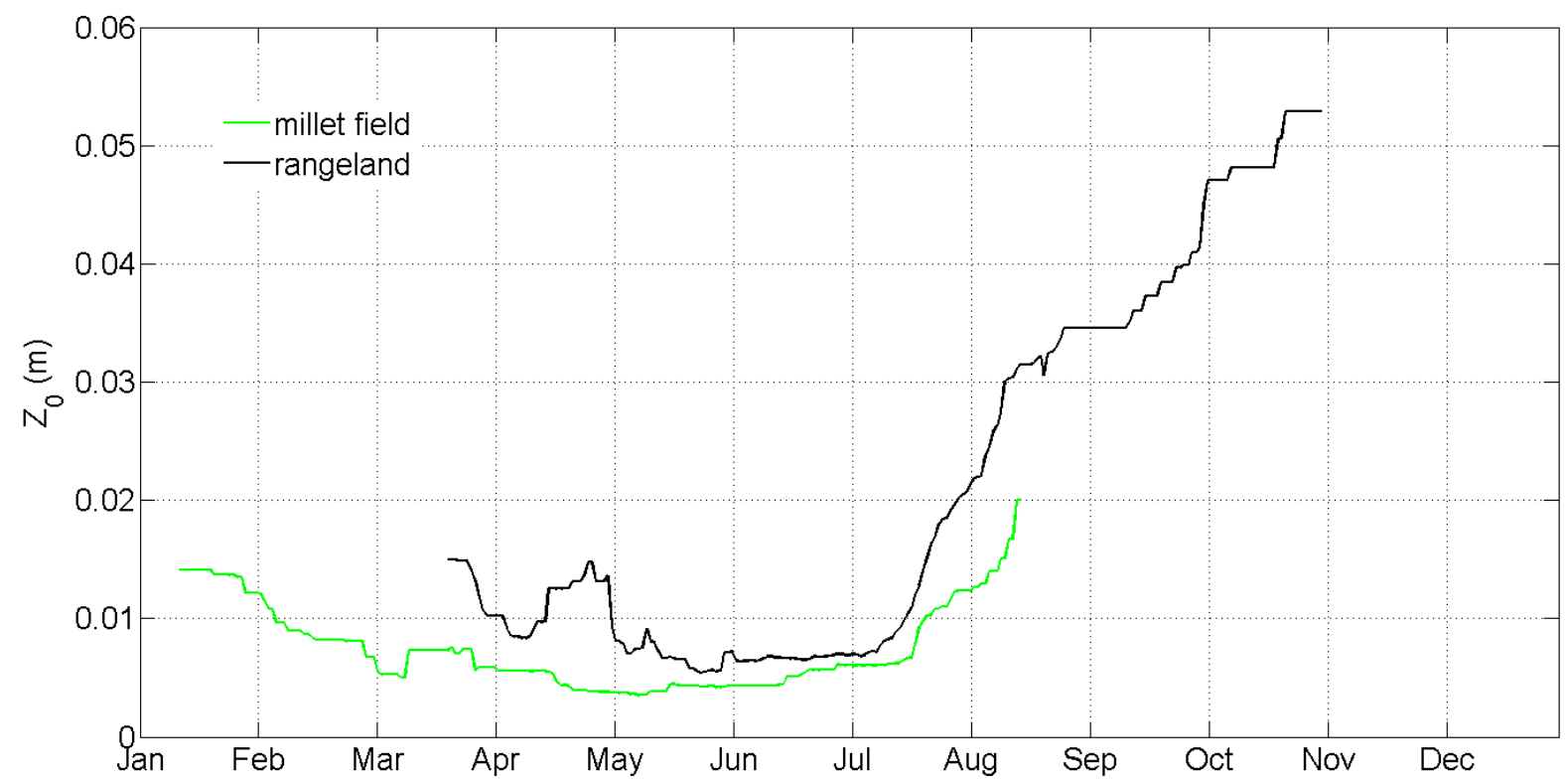

Figure 1: Mean annual cycle of the aerodynamic surface roughness length $\left(Z_{0}\right)$ estimated from measurements of wind velocity and wind friction velocity, for the Agoufou rangeland and the Banizoumbou millet field over 2006-2008.

The mean cycles imply that the rangeland $Z_{0}$ is greater than the millet $Z_{0}$ until mid-August. The marked increase in $Z_{0}$ corresponding to the start of the vegetation growth occurs earlier and is sharper for the rangeland (beginning of July) compared to the millet field (mid-July), despite the fact that the millet field is located about $2^{\circ}$ to the South, with on average an earlier rainy season (Frappart et al. 2009). Thus, the time shift between the $Z_{0}$ cycles may reflect the phenological offset 
between these two cover types, already observed for similar sites in Niger (Boulain et al., 2009; Velluet et al., 2014). Although these $Z_{0}$ estimates do not cover the whole year, they cover the period which is critical for wind erosion, i.e. the end of the dry season and the beginning of vegetation growth (e.g. Rajot, 2001; Abdourhamane Touré et al., 2011).

\subsection{Parameterizations of the aerodynamic roughness length $\left(Z_{0}\right)$}

\section{Agoufou site:}

Both standing straws and litter, which masses are respectively noted $\mathrm{BM}_{\text {std }}$ and $\mathrm{BM}_{\text {lit, }}$ inhibit wind erosion, although their respective effects may differ (Siddoway et al., 1965; Nandinstetseg and Shinoda, 2015). Consequently, the $Z_{0}$ parameterization should take into account these two types of obstacles separately. Monthly means of $Z_{0}$ estimates are regressed against monthly means of the measured vegetation mass. Separate linear regressions are computed depending on data availability for the dry (March to June) and wet (July to September) seasons, giving respectively the coefficients for litter $\left(R^{2}=0.63, n=3\right)$ and for standing vegetation $\left(R^{2}=0.74, n=4\right)$ of the final parameterization. In this way, the coefficients performing best for the dry season and the beginning of the growing season are estimated. The following parameterization is obtained for grass:

$\mathrm{Z}_{0}=0.0003 \mathrm{BM}_{\mathrm{std}}+0.0007 \mathrm{BM}_{\mathrm{lit}}$

with $B M$ expressed in $g \cdot \mathrm{m}^{-2}$ and $Z_{0}$ in $\mathrm{m}$. This regression is used for $Z_{0}$ values greater than the aerodynamic surface roughness of the bare surface $z_{0 s}=9.710^{-5} \mathrm{~m}$, a typical value for such a sandy site (see Pierre et al., 2014a).

\section{Banizoumbou site:}

Daily values of $Z_{0}$, interpolated from monthly means to each millet height measurement day, are regressed against measured millet height (2006 to 2008). Bare soil value being the intercept of these regressions, the smallest intercept values among the three years is selected. Because of $Z_{0}$ data scarcity, the slope is obtained from the regression over year 2008 only $\left(R^{2}=0.94, n=10\right)$, which exhibits a marked dynamics in millet heights and $Z_{0}$ estimates. The following parametrization is obtained for millet height lower than $1 \mathrm{~m}$ :

$\mathrm{Z}_{0}=0.016 * \mathrm{H}+0.003 \quad$ if $\mathrm{H}<1 \mathrm{~m}$

where $\mathrm{Z}_{0}$ and $\mathrm{H}$ are in $\mathrm{m}$.

Bielders et al. (2004) reported maximum values of $0.1 \mathrm{~m}$ for $Z_{0}$ in a similar millet field at Banizoumbou for years 1996 to 1998 . Thus, for millet higher than $1 \mathrm{~m}, \mathrm{Z}_{0}$ is parameterized so that it reaches $0.1 \mathrm{~m}$ for a millet height of $2.3 \mathrm{~m}$ :

$\mathrm{Z}_{0}=0.062 * \mathrm{H}-0.043 \quad$ if $\mathrm{H}>1 \mathrm{~m}$

with $\mathrm{Z}_{0}$ and $\mathrm{H}$ expressed in $\mathrm{m}$.

When only litter is left on the field (from early January to millet germination), $Z_{0}$ is adapted from the relation proposed by Abdourhamane Touré et al. (2011, Figure 11) to ensure continuity of $Z_{0}$ values: 
with $Z_{0}$ expressed in $\mathrm{m}$. At the beginning of millet growth, the maximum $Z_{0}$ between standing millet (Eq. (9)) and crop residues (Eq. (11)) is retained.

\subsection{Wind erosion modeling}

The wind erosion model has been described in Pierre et al. (2014b). The main principles are summarized hereafter. Wind erosion occurs when the wind friction velocity exceeds a threshold value that depends on the presence of non erodible elements - such as vegetation - on the surface (Bagnold, 1941; Gillette, 1979) and on the topsoil layer characteristics (e.g., surface soil moisture). Water in the soil strengthens the cohesive forces linking the soil grains together, increasing the threshold wind friction velocity. This effect is estimated through the empirical relationship proposed by Fécan et al. (1999):

$$
M(w)=\left\{\begin{array}{cc}
1 & \text { if } w<w_{0} \\
{\left[1+1.21\left(w-w_{0}\right)^{0.68}\right]^{0.5}} & \text { if } w>w_{0}
\end{array}\right.
$$

where $w$ is the gravimetric soil moisture and $w_{0}$ is the residual gravimetric soil moisture (in $\% \mathrm{~g} \cdot \mathrm{g}^{-1}$ ), which depends on the soil texture. $w_{0}$ is derived from the soil clay content following Fécan et al. (1999):

$w_{0}=0.0014\left(\%_{\text {clay }}\right)^{2}+0.17\left(\%_{\text {clay }}\right)$

This yields a residual soil moisture close to zero for very sandy soils like the ones of Banizoumbou and Agoufou. This parameterization was applied to the Agoufou site, where soil moisture was monitored at $0.05 \mathrm{~m}$ depth. An estimate of soil moisture at $0.01 \mathrm{~m}$ depth is derived from these measurements, based on rainfall dynamics following Pierre et al. (2014b). The soil moisture estimate at $0.01 \mathrm{~m}$ depth is assumed to be equal to the soil moisture at $0.05 \mathrm{~m}$ depth during a rain event, and then to decrease to a minimum value 36 hours later. Since soil moisture is not available at Banizoumbou, the simulated wind erosion for this site is inhibited as soon as rain exceeds $1 \mathrm{~mm}$ in 1 hour, and during 24 hours afterwards, as in Pierre et al. (2014a).

Because of the non erodible elements, the friction velocity exerted on the surface between obstacles $\left(u_{s^{*}}\right)$ is less than the total friction velocity of the wind $\left(u_{*}\right)$. Marticorena and Bergametti (1995) defined the effective fraction $\left(f_{\text {eff }}\right)$ as the ratio of $u_{s^{*}}$ over $u_{*}$. The following expression results from the correction proposed by these authors, as stated in King et al. (2005):

$$
\frac{u_{s^{*}}}{u *}=f_{e f f}=1-\frac{\ln \left(\frac{z_{0}}{z_{0 s}}\right)}{\ln \left(\left(0.7 * \frac{\mathrm{X}}{z_{0 S}}\right)^{0.8}\right)}
$$


where $z_{0 s}$ is the aerodynamic roughness of the bare soil, $Z_{0}$ is the aerodynamic roughness length of the surface (including the obstacles) and $X$ is tied to the height of the internal boundary layer that develops between the obstacles ( $z_{0 s}, Z_{0}$ and $X$ are in the same length unit).

The parameter $X$ is set to $X=0.4 \mathrm{~m}$, in agreement with Pierre et al. (2014a). The threshold friction velocity $\left(\mathrm{u}_{t^{*}}\right)$ is obtained from the effective fraction and the effect of soil moisture, assuming a threshold friction velocity for the bare soil of $u_{t^{*}}=0.22 \mathrm{~m}^{-1} \mathrm{~s}^{-1}$, as in Pierre et al. (2014b):

$u_{t *}=M(w) \frac{u_{t s *}}{f_{e f f}}$

The friction velocity is computed with Eq. (7) from the simulated $Z_{0}$ and the measured wind speed for each cover type. Wind erosion is computed at the time step of the wind measurements, i.e. 15minute at Agoufou and 5-minute at Banizoumbou. When the threshold friction velocity is exceeded, particle entrainment occurs, and the particle mass flux depends on a power function of the wind friction velocity. As in Marticorena and Bergametti (1995), the horizontal flux G (in kg. $\mathrm{m}^{-1} \cdot \mathrm{day}^{-1}$ ) also called saltation flux - is estimated following Kawamura (1951) and White (1979), taking into account the fraction of erodible surface $\mathrm{E}$ :

$G=E \frac{\rho_{a}}{g} u_{*}^{3}\left(1+\frac{u_{t *}}{u_{*}}\right)\left(1-\left(\frac{u_{t *}}{u_{*}}\right)^{2}\right)$

where $\rho_{a}$ is the density of air (equal to $1.227 \mathrm{~kg} \cdot \mathrm{m}^{-3}$ ).

The horizontal flux is computed over 2006 to 2008. For the Banizoumbou millet case, the results are compared to the 10 highest values of the monitoring sand traps, as in Pierre et al. (2014a). Indeed, the wind erosion model is designed to simulate a steady state flux, which is not reached at all locations of the instrumented plot. For consistency, measured horizontal flux is not considered when gaps in wind data preclude simulations.

\section{Results and discussion}

\subsection{Vegetation cover}

\section{Agoufou site:}

The outputs of the two vegetation models show differences in vegetation masses (Figure 2): the mass of millet is larger than that of grass during most of the dry seasons of 2006-2007 and 20072008. This is a direct consequence of higher millet production at the end of the rainy season, for which annual rainfall tallied 376 and $287 \mathrm{~mm}$ in 2006 and 2007 respectively. However, millet mass becomes smaller than grass mass at the very end of the dry season (from March on). The seasonal dynamics also differs: growth starts and vegetation mass reaches a maximum about 1 month later for millet than for rangeland in 2006 and 2007. Yet, the simulated germination occurs at the same period for both grass and millet, but the simulated millet mass during the first phenological stages remains very low. After harvest, millet leaves - but not stems - disappear quickly (not shown), eaten and trampled by livestock. At field clearing (January $1^{\text {st }}$ ), remaining standing millet stems are turned into litter, which causes litter mass to peak. 


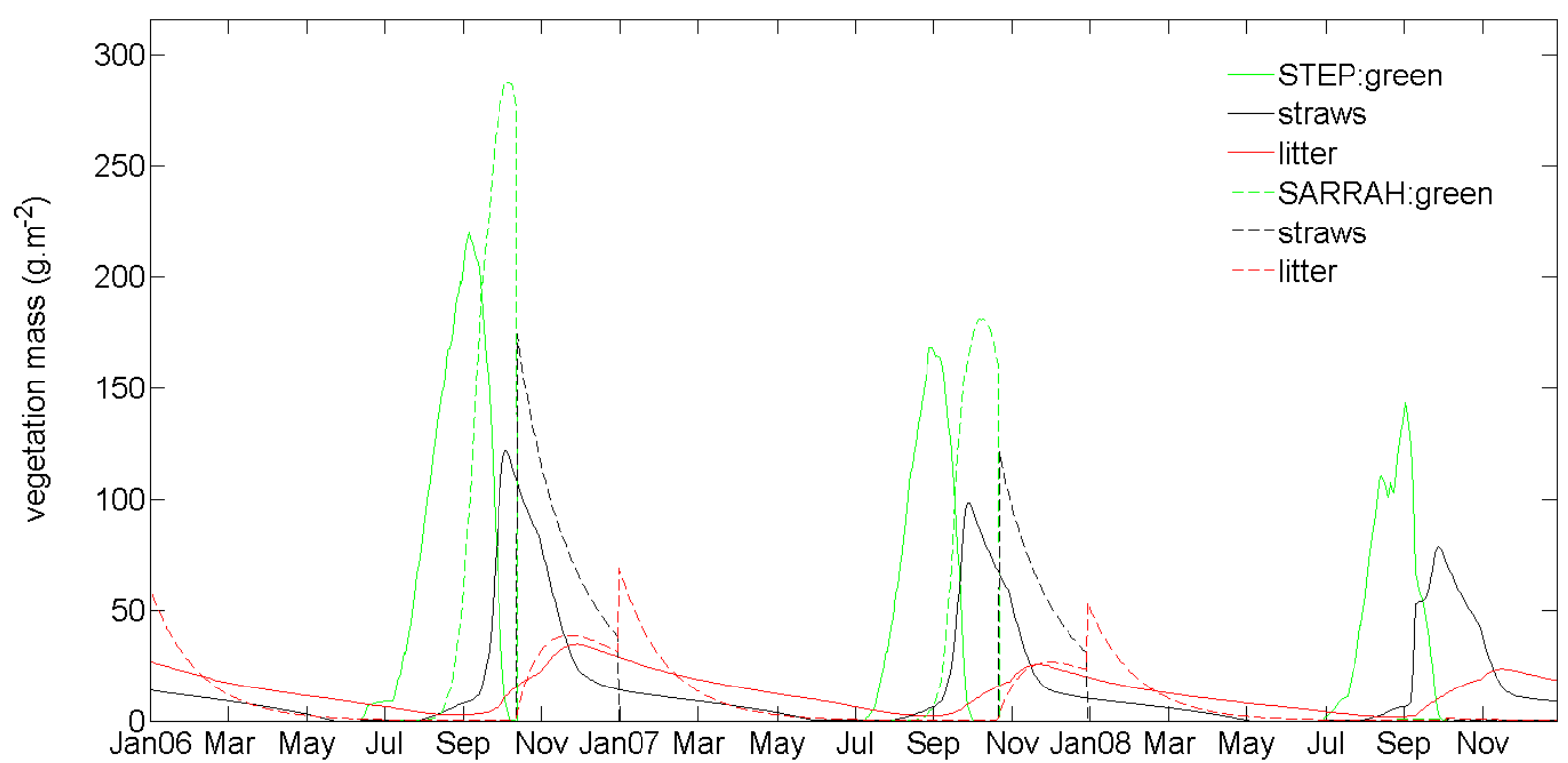

Figure 2: Green, straw and litter mass at Agoufou from 2006 to 2008, for rangeland grass according to the STEP model (solid lines) and for millet according to the SarraH model (dotted lines). STEP simulations are adapted from Delon et al. (2015)

The decrease in rainfall over the 3 years has a strong impact on the simulated vegetation. Year 2008 is dry $(227 \mathrm{~mm})$ and the SarraH model does not simulate any millet growth. This is reasonable since Agoufou is at the northern boundary of millet crops in Mali, and millet growth and yield are very variable. Moreover, rainfall events are more scattered over time in 2008, the rainy season lasting 165 days (starting on April 30 ${ }^{\text {th }}$ ), against 132 days (May 27 $7^{\text {th }}$ ) and 137 days (June $6^{\text {th }}$ ) in 2006 and 2007. Dryspells interrupt plant growth by inducing water stress, particularly at the beginning of the rainy season: in 2008, there is no rain during 24 days after the first rain events. Millet maximum occurs rather late in 2007 (around mid-October), but this date is still consistent with field observations (indicating a maximum between early September and mid-October).

There is a good agreement between STEP simulations and field measurements at the Agoufou rangeland site (Figure 3): green vegetation mass and dynamics are well reproduced, as well as the dry season dynamics. The simulated cover fraction is also in good agreement with measurements (not shown). There might be a slight overestimation of peak vegetation mass, although in situ measurements may not fit exactly the date of maximum mass, and a slight underestimation of litter mass by the model from January to May in 2007 and 2008. 


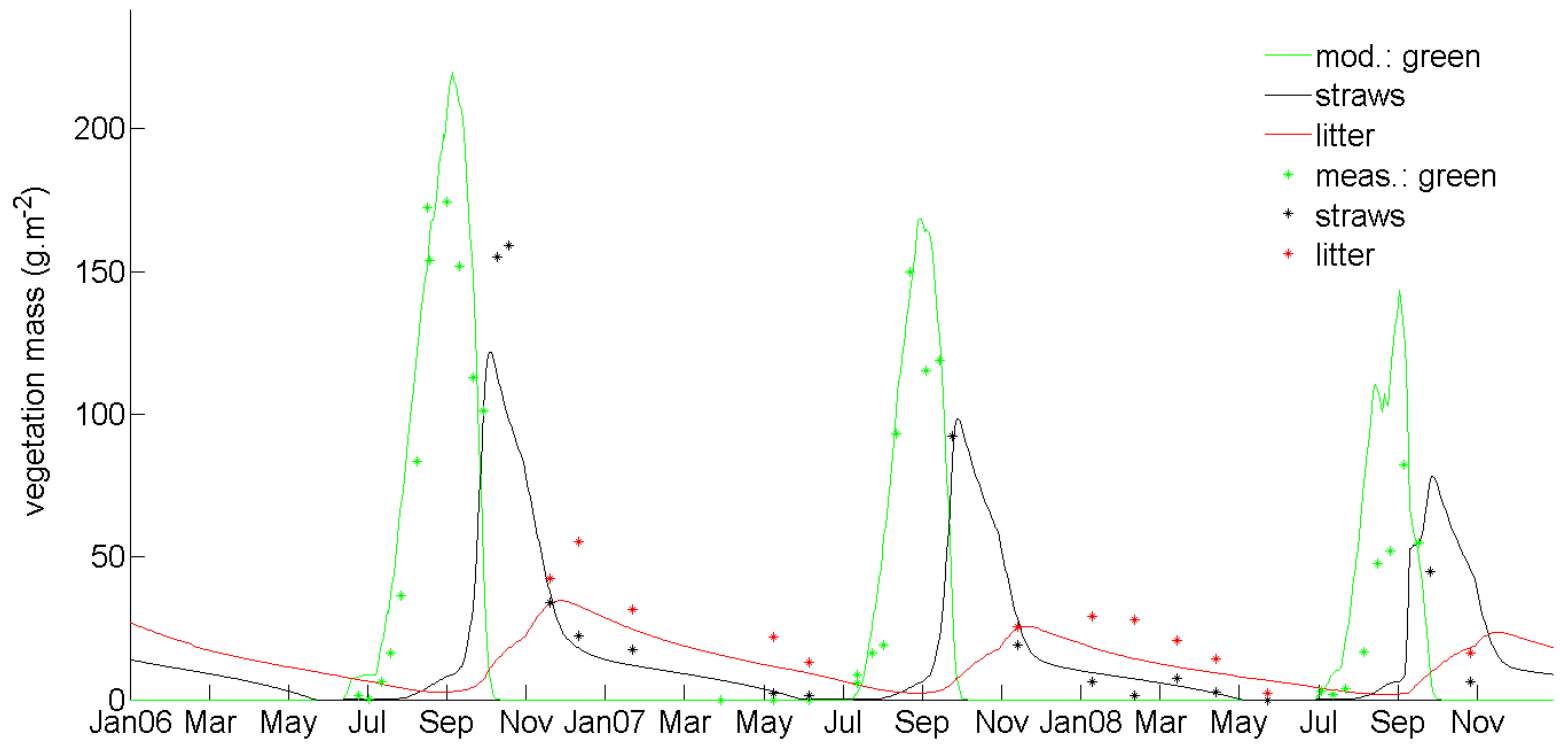

Figure 3: Green, straw and litter mass for rangeland grass at Agoufou from 2006 to 2008, according to the STEP model (solid lines) and to measurements (stars). Adapted from Delon et al. (2015).

\section{Banizoumbou site:}

Banizoumbou annual rainfall is $503 \mathrm{~mm}$ (2006), $456 \mathrm{~mm}$ (2007) and $700 \mathrm{~mm}$ (2008): thus rainfall in the two first years is close to average, while year 2008 is above average (see 2.1). Interannual variability over the 3 years is different at Banizoumbou and Agoufou, which is expected given the 500 $\mathrm{km}$ distance between the two sites and the spatial variability of Sahelian rainfall (Balme et al., 2006). Although the annual rainfall at Banizoumbou are greater than at Agoufou, they lead to lower simulated biomass at Banizoumbou in 2006 and 2007 (Figure 4). This mainly results from the distribution of precipitation during the rainy season. Indeed, the rainy season at Banizoumbou lasts 127 days (and starts on May 27 $7^{\text {th }}$ ), 130 days (May $7^{\text {th }}$ ) and 144 days (May 21 $1^{\text {st }}$ ) in years 2006, 2007 and 2008 respectively. A one week long dryspell occurs from June $10^{\text {th }}$ in 2006 , while three other dryspells occur between the first rain events in 2007 and two at the beginning of the rainy season in 2008. In 2006, the cumulated rainfall in June is very low, triggering an important water stress. In addition, the simulated grain filling occurs relatively early this year, which prevents millet to take full advantage of the whole rainy season. Conversely, ample precipitation in 2008 lead to a peak biomass in the upper range of what moderately manured fields can produce (e.g. Rockstrom and de Rouw, 1997; Schlecht et al., 2004). The lower soil fertility for rangeland in Banizoumbou compared to Agoufou (see 2.3) contributes to lower the simulated grass mass in Banizoumbou compared to Agoufou.

As for the Agoufou site, there is a time shift in growth between the millet field and the rangeland, millet growth being delayed compared to that of grass. There is also a lower biomass maximum for grass than for millet, as expected for this area (Dardel et al 2014). During the dry season, particularly from March on, and as for the Agoufou site, less crop residues remain on the field compared to straws and litter on the rangeland. 


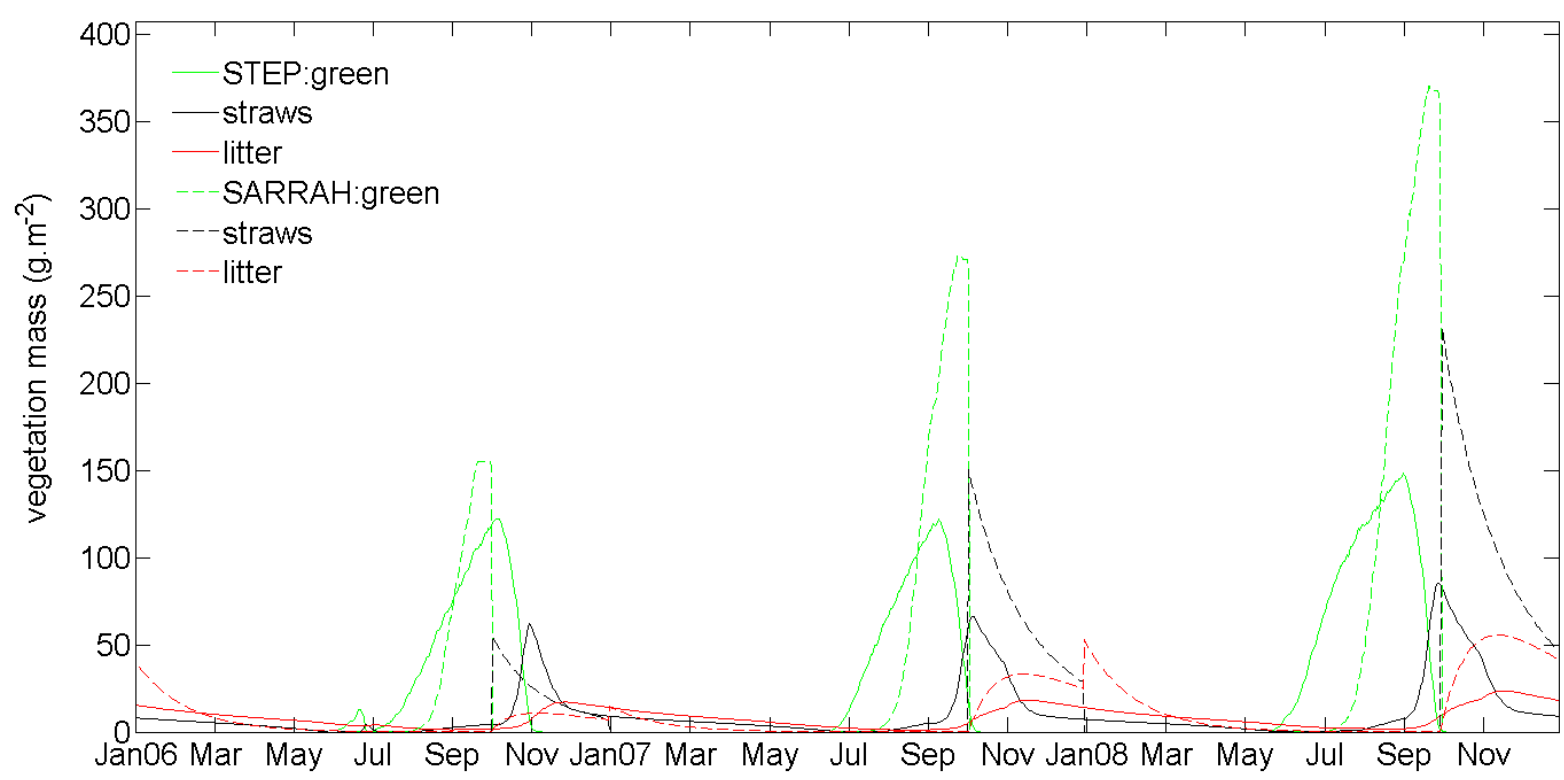

Figure 4: Green, straw and litter mass at Banizoumbou from 2006 to 2008, for rangeland grass according to the STEP model (solid lines) and for millet according to the SarraH model (dotted lines).

Applying Eq. (6) to the SarraH model outputs results in simulated millet height that fits measured millet height satisfyingly (Figure 5). However, the simulated growth onset is slightly delayed in 2008 and slightly advanced in 2006 compared to observations. The impact of this simulation delay on wind erosion simulations will be discussed below.

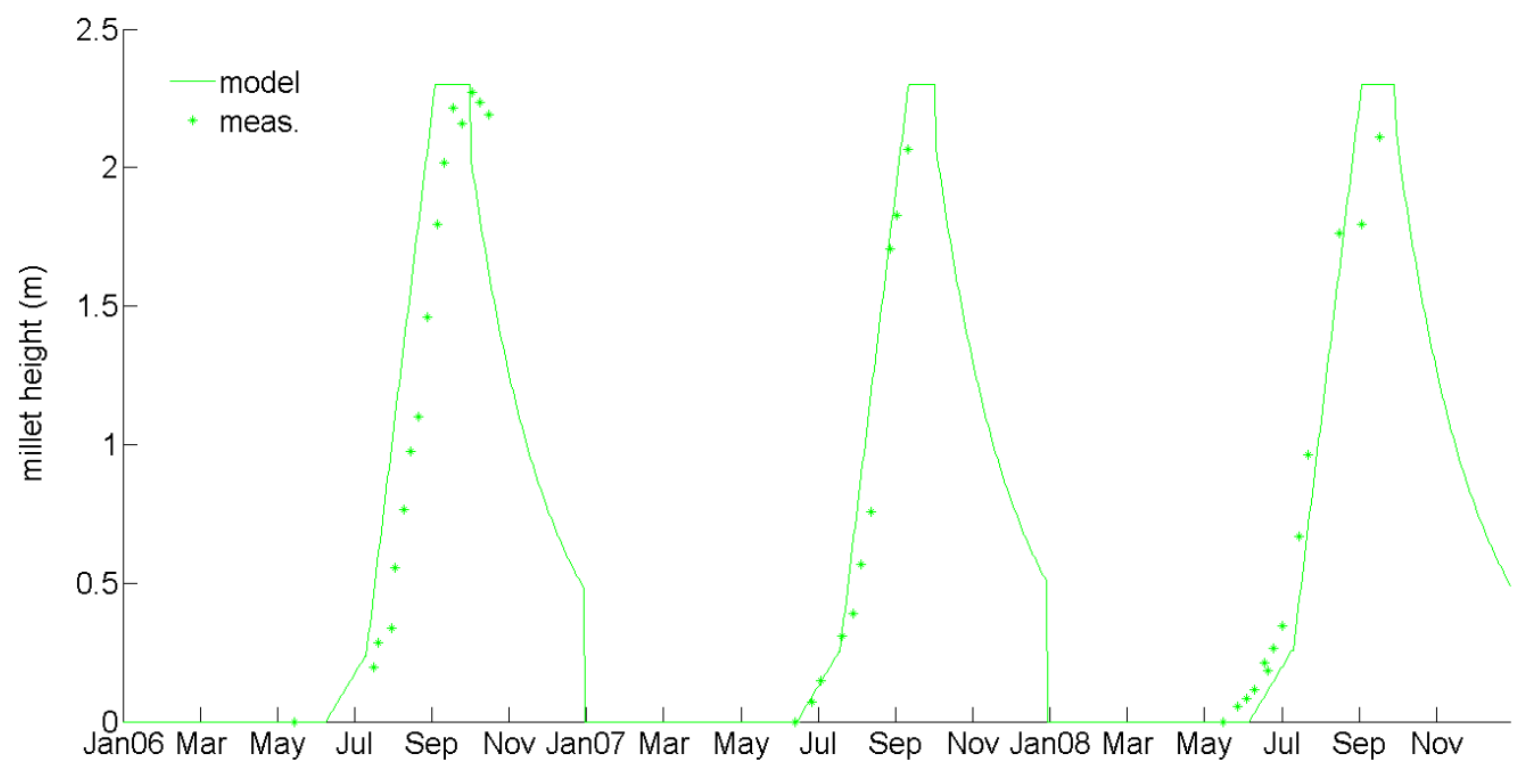

Figure 5: Measured (stars) and parameterized (line) millet height according to the phenological phases simulated by the SarraH model at Banizoumbou from 2006 to 2008. 


\subsection{Surface characteristics}

\section{Agoufou site:}

$Z_{0}$ estimates from Eq. (8) and the STEP model outputs are in good agreement with measured $Z_{0}$ (Figure 6). Over 2006 and 2007, $Z_{0}$ estimates and parameterized values correlate with a coefficient $\mathrm{R}^{2}=0.74$ ( $\mathrm{n}=307$ ), with RMSE $=0.008 \mathrm{~m} . \mathrm{Z}_{0}$ dynamics during the late dry season are well reproduced, as well as the onset of growth at the beginning of the rainy season. During the rest of the year, the $Z_{0}$ dynamics corresponds to what is expected: a peak in September is followed by a rapid decrease due to senescence and to trampling and intake by livestock. The slope of this decrease is in good agreement with measurements performed from March to May 2006 and during June 2007. $Z_{0}$ are not as well reproduced late in the rainy season in 2007, but this is not critical because wind erosion is negligible during this part of the year. Additionally, the minimum and maximum values of the aerodynamic roughness length are also in good agreement with the existing literature (Marticorena et al., 2006; Tidjani et al., 2009).

Except at vegetation maximum, the parameterized $Z_{0}$ for the rangeland is significantly higher than the one parameterized for the millet field. A well marked time shift of growth onset of about one month is simulated between the two cover types. As the SarraH model does not simulate any millet growth in 2008, the corresponding $Z_{0}$ is only due to the degradation of the litter from the previous year.

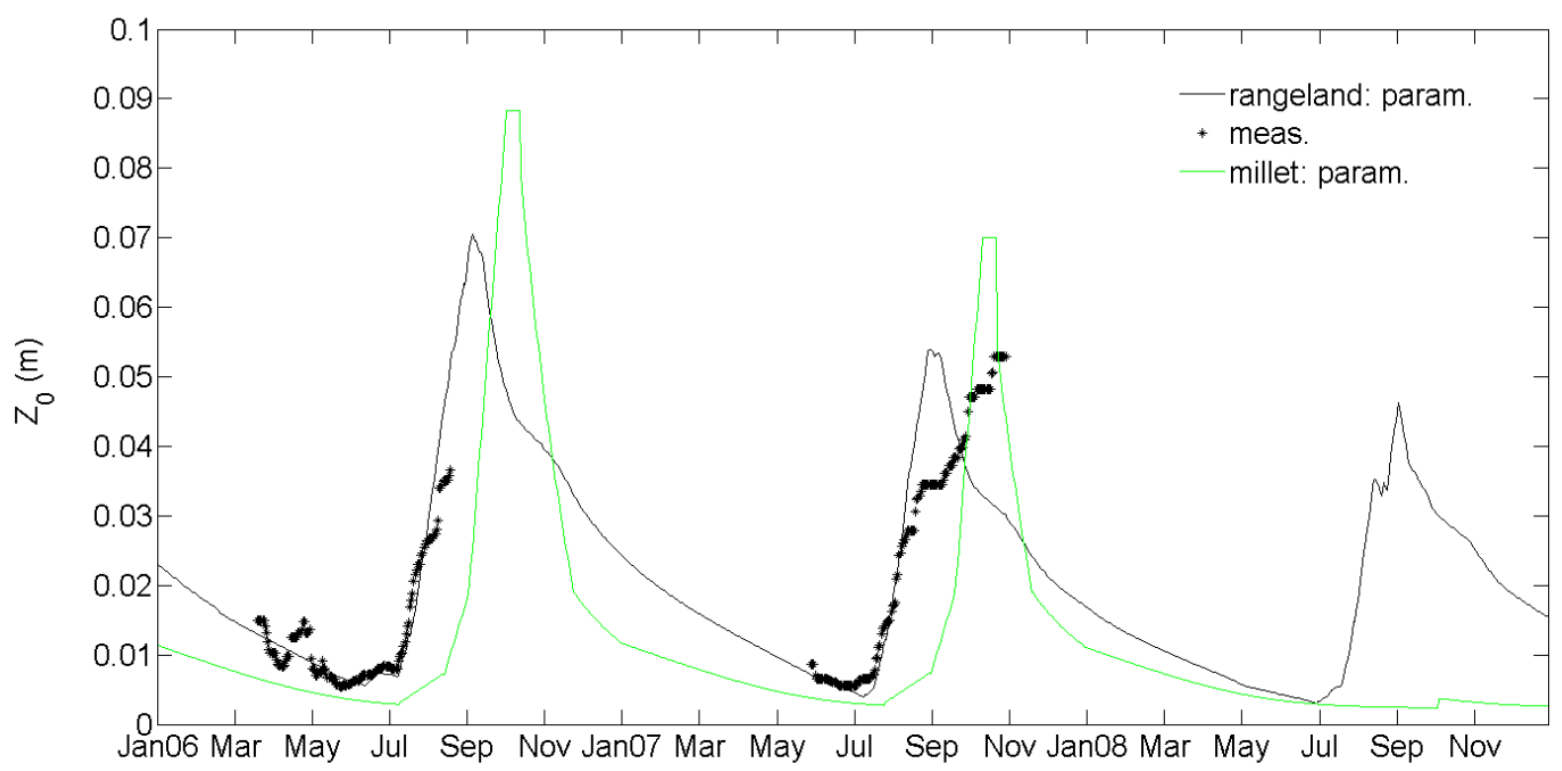

Figure 6: Rangeland measurements (stars) and rangeland and millet parameterized $Z_{0}$ based on vegetation mass simulated by the STEP model and based on millet height according to the SarraH model at Agoufou from 2006 to 2008.

The vegetation cover fraction - taking into account green and dry vegetation - is similar for both cover types in 2006 and 2007, with slightly higher values for rangeland (Figure 7). While millet can reach height greater than $2 \mathrm{~m}$, it is usually planted in clusters (or "hills") one meter apart in average, yielding a lower cover fraction than for the low grass patches. However, the rangeland is not homogeneous, with bare soil patches varying in size during the season (Pierre et al., 2014b). The maximum cover value of $40 \%$ for millet is in agreement with measurements reported by Levy and 
Jarvis (1999) for a millet field in Niger. The seasonal dynamics again show an earlier growth for the rangeland than for the millet field. The millet cover fraction shows a discontinuity on January $1^{\text {st }}$ because remaining millet straws are laid down for field clearing.

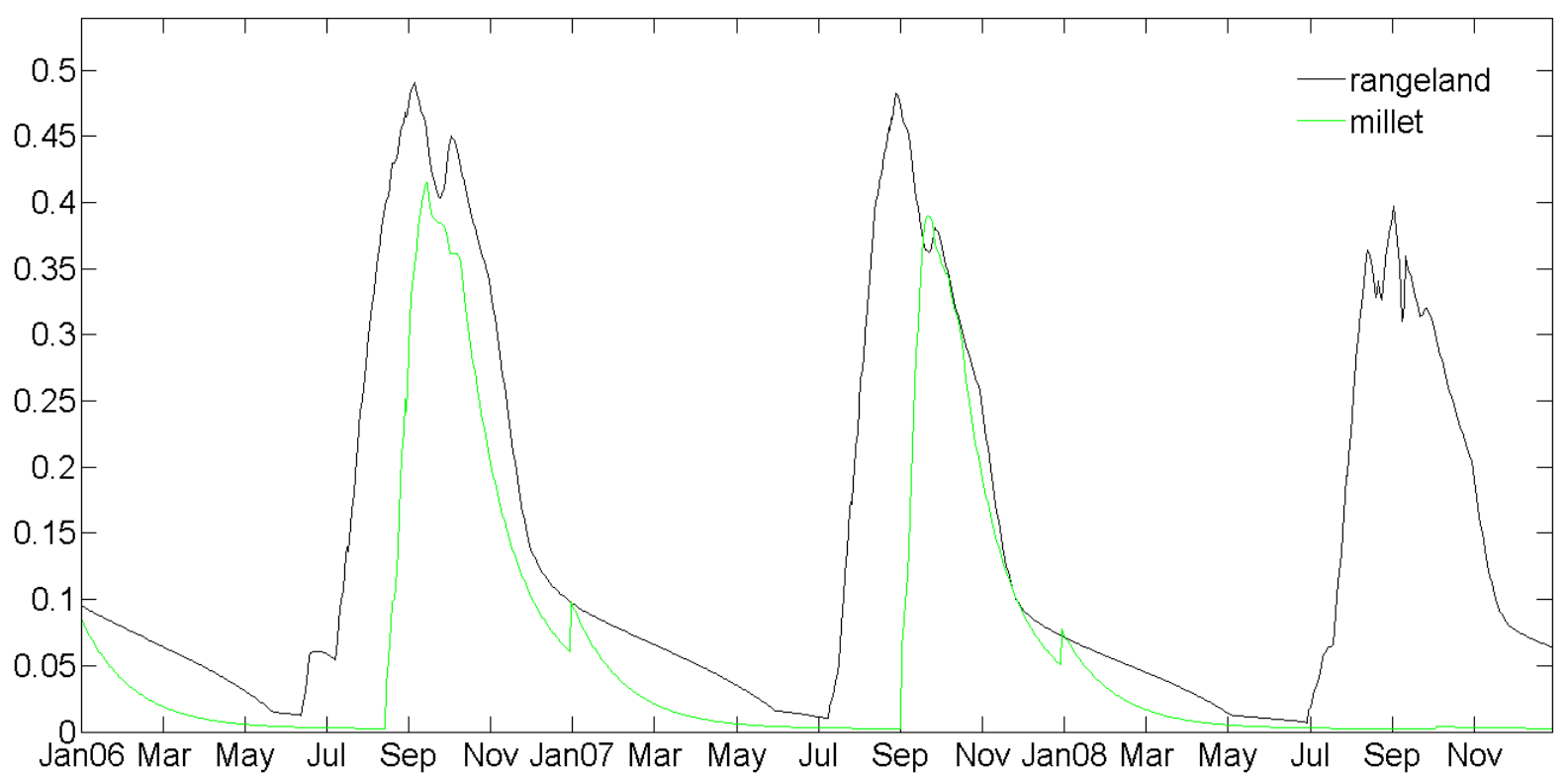

Figure 7: Vegetation cover fraction estimated from the outputs of the STEP and SarraH models at Agoufou from 2006 to 2008.

\section{Banizoumbou site:}

$\mathrm{Z}_{0}$ derived from Eq. (9) to (11) applied to the modeled millet at Banizoumbou shows a reasonable agreement with measurements at the end of the dry season in all years, and at the beginning of the rainy season in 2008 (May to July) (Figure 8). For the 3 years, $Z_{0}$ estimates and parameterized values correlate with a coefficient $R^{2}=0.21(n=555)$ and a $R M S E=0.011 \mathrm{~m}$. This rather poor agreement is due to the low variability of $Z_{0}$ estimates over this period, except for year 2008. When considering year 2008 only, the agreement between parameterized and estimated $Z_{0}$ reaches a correlation coefficient of $R^{2}=0.91(n=220)$ and $R M S E=0.003 \mathrm{~m}$. This suggests that Eq. (9) allows to reproduce reasonably $Z_{0}$ values in the late dry season, and its increase at the beginning of vegetation growth.

There is a tendency to overestimate $Z_{0}$ in the early growing season $(2006,2007)$ but not in 2008 , which reflects the early simulated germination these years. The sudden decrease of $Z_{0}$ on January $1^{\text {st }}$ is due to field clearing. The slope change observed in August corresponds to a change in millet phenology according to the SarraH model. The millet $Z_{0}$ values exhibit slightly larger values than in Abdourhamane Touré et al. (2011) and Pierre et al. (2014a). This is mainly due to the fact that the present study considers a longer period of the year. 


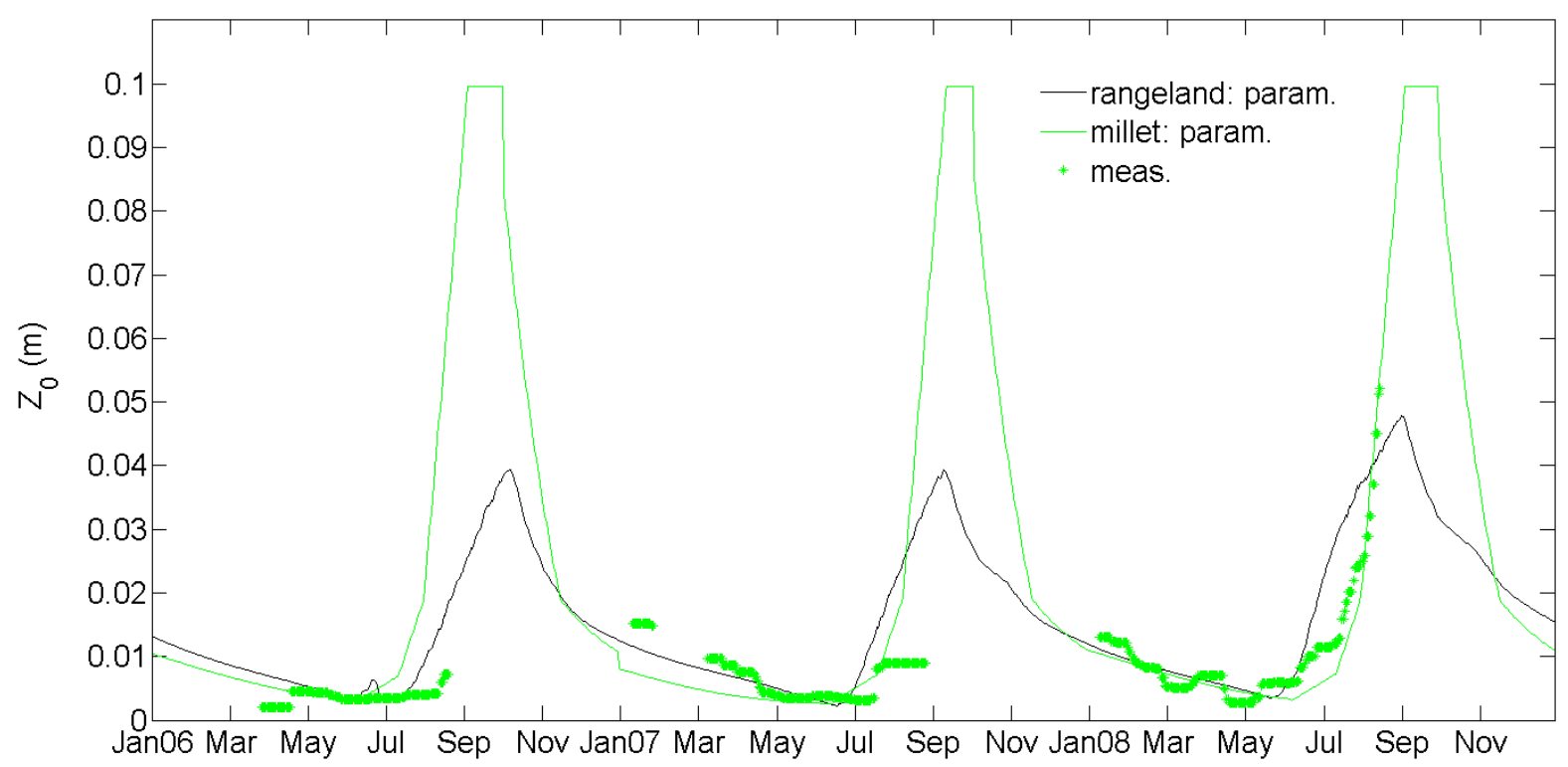

Figure 8: Millet measurements (stars) and rangeland and millet parameterized $Z_{0}$ based on vegetation mass simulated by the STEP model and based on millet height according to the SarraH model at Banizoumbou from 2006 to 2008.

As in Agoufou, the rangeland $Z_{0}$ is slightly higher than that of millet field during the dry season, but the difference is smaller. Similarly, there is a time shift in plant growth between the two cover types, except in 2006 because of an earlier millet simulated germination. In this year, according to the SarraH model, the first millet plants that germinate survive the early season water stress, whereas STEP simulates a second germination after the stress period. The rangeland $Z_{0}$ in Banizoumbou are lower than in Agoufou rangeland because of a lower grass mass simulated by the STEP model. Conversely, the Agoufou millet $Z_{0}$ does not reach the maximum value of $0.1 \mathrm{~m}$ (Figure 6 ), because the simulated millet cycle at Agoufou is shorter (96 and 89 days in 2006 and 2007) than at Banizoumbou (115, 110 and 116 days for 2006, 2007 and 2008). This mainly reflects the meteorological difference between the two sites (higher temperature and lower rainfall in Agoufou than in Banizoumbou, and different length of the photoperiodic stage due to difference in latitude between the two sites). This difference is less sensitive in the case of the rangeland because degree-days are not considered in the STEP model. 


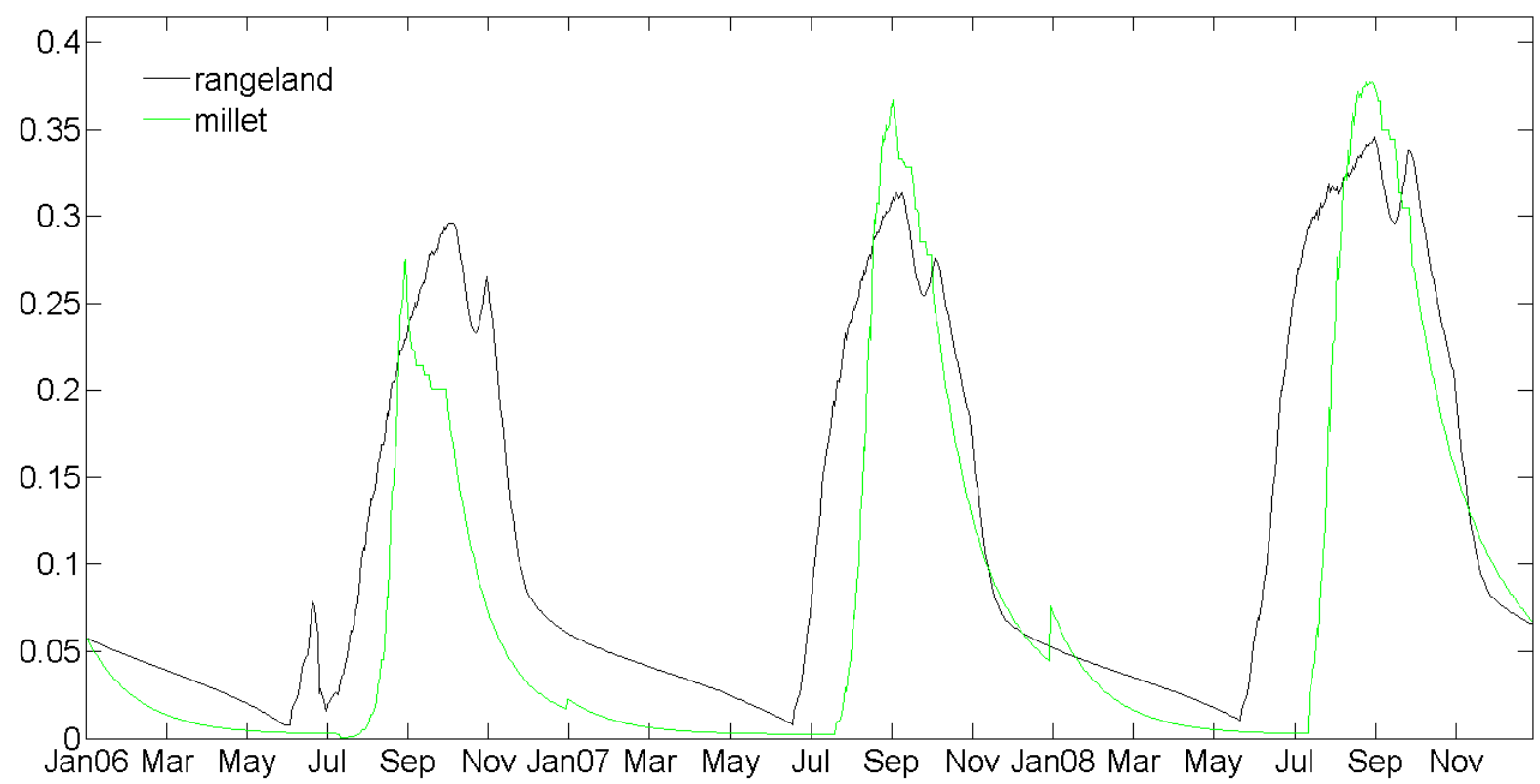

Figure 9: Vegetation cover fraction estimated from the outputs of the STEP and SarraH models at Banizoumbou from 2006 to 2008.

Vegetation cover fractions in Banizoumbou show similar patterns than those in Agoufou, with larger values for rangeland than for millet - except at vegetation maximum.

\subsection{Wind erosion}

\section{Agoufou site:}

The simulated threshold friction velocities $\left(u_{t^{*}}\right)$ exhibit strong seasonal dynamics (Figure 10). For both millet and grass, except for the failed millet crop in 2008, wind erosion is completely inhibited from approximately August to November because of an important vegetation cover and roughness, combined with less frequent strong winds and a more frequently wet soil. During rainfall events, which occur from June to September, soil moisture induces abrupt and brief increases of the threshold friction velocity by about a factor of 2 compared to baseline values. Over the 3-year period, $u_{t^{*}}$ is usually higher in the rangeland than in the cropland. $u_{t^{*}}$ reaches minimum values of about 0.48 $\mathrm{m} . \mathrm{s}^{-1}$ in the rangeland and $0.45 \mathrm{~m} . \mathrm{s}^{-1}$ in the millet field, with significant interannual variability: in the rangeland, the annual minimum threshold is reached in June $\left(8^{\text {th }}\right)$ for year $2006\left(0.62 \mathrm{~m} . \mathrm{s}^{-1}\right)$, and in July $\left(11^{\text {th }}\right.$ and $\left.2^{\text {nd }}\right)$ for years $2007\left(0.54 \mathrm{~m} . \mathrm{s}^{-1}\right)$ and $2008\left(0.48 \mathrm{~m} . \mathrm{s}^{-1}\right)$. These values are higher than the values of 0.26 to $0.49 \mathrm{~m} . \mathrm{s}^{-1}$ reported by Tidjani et al. (2009) on a heavily grazed dune, probably because the Agoufou site is less grazed than their study site. In the millet field, the annual minimum threshold is reached in July $\left(7^{\text {th }}\right.$ and $\left.25^{\text {th }}\right)$ for years $2006\left(0.48 \mathrm{~m} . \mathrm{s}^{-1}\right)$ and $2007\left(0.47 \mathrm{~m} . \mathrm{s}^{-1}\right)$, thus 2 to 4 weeks later than for the rangeland. In 2008, no millet growth is simulated and the threshold friction velocity in the millet field is only influenced by litter degradation. 

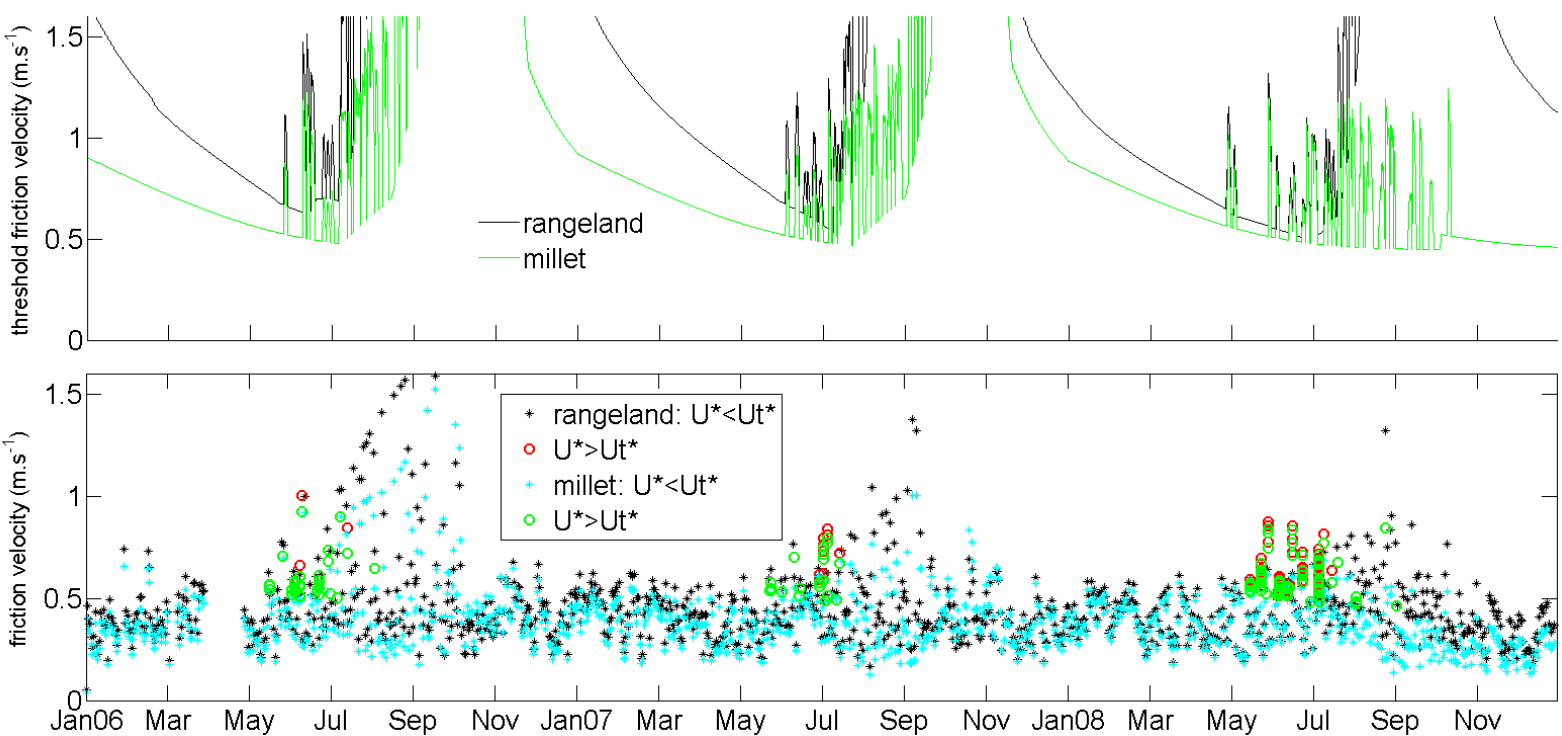

Figure 10: Threshold wind friction velocity and wind friction velocity for the rangeland and the millet field at Agoufou from 2006 to 2008, based on vegetation simulations.

In line with previous studies dealing with wind erosion on Sahelian surfaces (Rajot, 2001; Abourhamane Touré et al., 2011; Ikazaki et al., 2011), most of the horizontal flux occurs during the late dry and early rainy seasons, for both cover types (Figure 11). At this period of the year, the vegetation is mainly composed of standing straws and litter in the rangeland, and of litter in the millet field. The lower $\mathrm{u}_{t^{*}}$ of the millet field leads to greater and more frequent wind erosion events than for the rangeland. During the 3 years, there are 17 days with a horizontal flux greater than 1 $\mathrm{kg} \cdot \mathrm{m}^{-1}$ in the rangeland, against 40 in the millet field.

The largest events are caused by gust fronts from deep convection occurring nearby and usually bringing rainfall. Each year, the largest event occurring in the rangeland contributes to $40 \%$ to $85 \%$ in mass of the annual horizontal flux. During these events, wind speed, averaged over 15 minutes, reaches values of about $16 \mathrm{~m} . \mathrm{s}^{-1}$ at $3.5 \mathrm{~m}$ above the surface. Such events occur on June $10^{\text {th }}$ in 2006 , on July $4^{\text {th }}$ in 2007 and on July $7^{\text {th }}$ in 2008. These dates also correspond to the annual largest events simulated in the millet field with similar absolute values but a lesser contribution to the annual horizontal flux (only 20 to $44 \%$ in mass depending on the year). The events of July $4^{\text {th }}, 2007$ and July $7^{\text {th }}, 2008$, correspond to high wind speed from a gust front not followed by rain. After the rainy season in 2008, saltation still occurs on the millet field because no millet has grown. However, these saltation events are very low (34 kg. $\mathrm{m}^{-1}$ from August to December) compared to the horizontal flux simulated for the May-July period $\left(1052 \mathrm{~kg} \cdot \mathrm{m}^{-1}\right)$, because of the inhibition effect of soil moisture during the late rainy season and less frequent strong winds during the early dry season. 


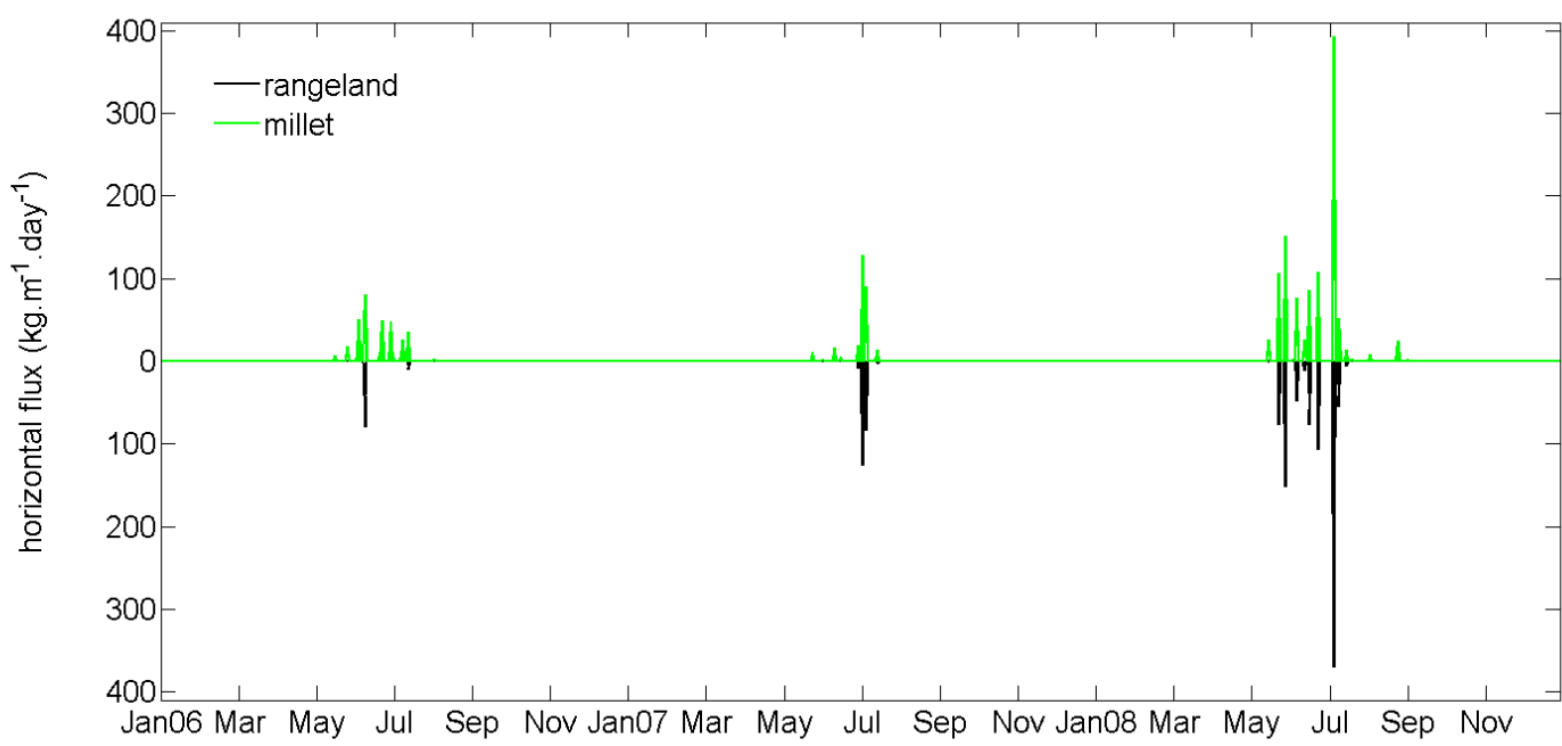

Figure 11: Simulated daily horizontal flux for the rangeland and the millet field at Agoufou from 2006 to 2008.

Cumulative horizontal fluxes over the 3 years are $1217 \mathrm{~kg} \cdot \mathrm{m}^{-1}$ for the rangeland and $1749 \mathrm{~kg} \cdot \mathrm{m}^{-1}$ for the millet field (Table 2). Each year, the horizontal flux is greater in the millet field than in the rangeland. These flux values exhibit a strong interannual variability, with the largest horizontal fluxes occurring during the driest year, 2008. Simulated straw and litter masses in June depend on the productivity of the previous year. Peak biomass is lower in 2007 than in 2005 (not shown) and 2006, therefore soil protection is lower in June for the year 2008. The interannual variability is also linked to the frequency of strong winds: respectively $1.4 \%, 1.2 \%$ and $1.7 \%$ of the wind speed data (at 3.5 $\mathrm{m}$ height) are higher than $7 \mathrm{~m} . \mathrm{s}^{-1}$ in 2006, 2007 and 2008. Overall, these results are consistent with the measurements performed in Niger by Rajot (2001, Table 1), who obtained a maximum horizontal flux of $600 \mathrm{~kg} \cdot \mathrm{m}^{-1} \cdot \mathrm{yr}^{-1}$ for a millet field.

Table 2: Simulated horizontal fluxes $\left(\mathrm{kg}^{\mathrm{m}} \mathrm{m}^{-1} \cdot \mathrm{yr} \mathrm{r}^{-1}\right)$ for the rangeland and the millet field at Agoufou from 2006 to 2008.

\begin{tabular}{|l|c|c|c|c|}
\hline & $\mathbf{2 0 0 6}$ & $\mathbf{2 0 0 7}$ & $\mathbf{2 0 0 8}$ & total \\
\hline Millet field & 376 & 288 & 1085 & 1749 \\
\hline Rangeland & 93 & 219 & 905 & 1217 \\
\hline
\end{tabular}

\section{Banizoumbou site:}

As in Agoufou, the threshold friction velocities are usually greater for the rangeland than for the cropland, and wind erosion is completely inhibited at vegetation maximum (Figure 12). $\mathrm{u}_{\mathrm{t}^{*}}$ does not take soil moisture into account because it was not monitored at Banizoumbou, thus the corresponding curve (Figure 12) is smoother than for Agoufou (Figure 10). However, in the simulations, wind erosion is inhibited after rainfall (see 2.6).

Threshold friction velocities show a slight interannual variability, with minimum values of $0.49 \mathrm{~m} . \mathrm{s}^{-1}$, $0.44 \mathrm{~m} . \mathrm{s}^{-1}$ and $0.50 \mathrm{~m} \cdot \mathrm{s}^{-1}$ being reached in the rangeland on June $5^{\text {th }}$ and $20^{\text {th }}$, and on May $25^{\text {th }}$ for years 2006, 2007 and 2008 respectively. In the millet field, minimum $u_{t^{*}}$ of $0.49 \mathrm{~m} . \mathrm{s}^{-1}, 0.46 \mathrm{~m} . \mathrm{s}^{-1}$ and $0.49 \mathrm{~m} . \mathrm{s}^{-1}$ are respectively reached on June $10^{\text {th }}$, June $17^{\text {th }}$ and June $9^{\text {th }}$ for years 2006,2007 and 
2008, thus several days later than in the rangeland, except in 2007. Values for millet are slightly higher than those reported by Abdourhamane Touré et al. (2011). These authors estimated values of $0.46 \mathrm{~m} . \mathrm{s}^{-1}$ in April to $0.36 \mathrm{~m} . \mathrm{s}^{-1}$ in July from measurements of soil particles impacts, while the present study yields approximately $0.56 \mathrm{~m} \cdot \mathrm{s}^{-1}$ to $0.48 \mathrm{~m} \cdot \mathrm{s}^{-1}$ for the same periods.
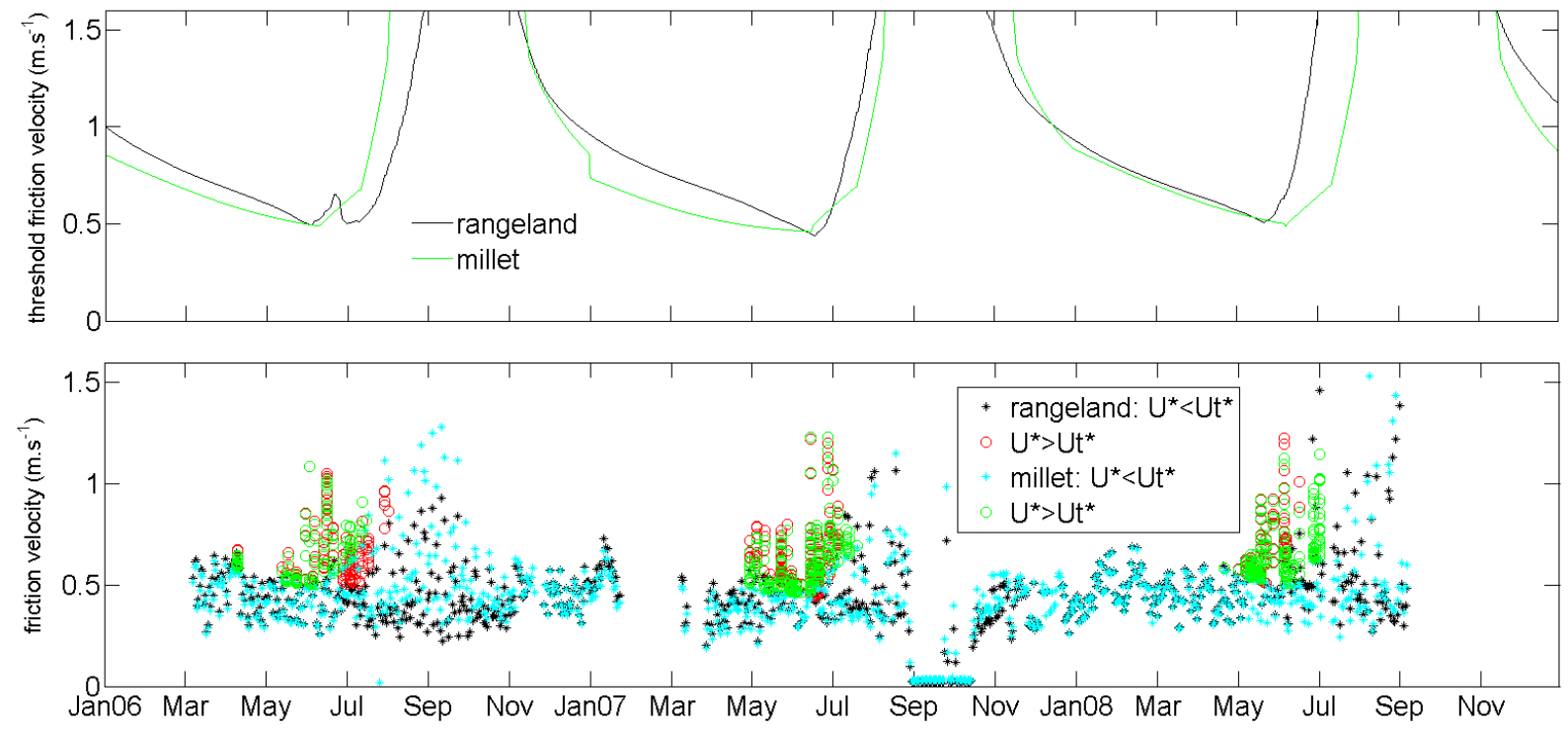

Figure 12: Threshold wind friction velocity and wind friction velocity for the rangeland and the millet field at Banizoumbou from 2006 to 2008, based on vegetation simulations.

Also in line with previous studies, most of the erosion takes place from May to July (Figure 13), when friction velocity can exceed threshold friction velocity. As in Agoufou, wind erosion events are more frequent in the millet field - particularly in May - than in the rangeland, but the largest events occur at the same dates for both surfaces. Over the 3 years, there are 38 days with a simulated horizontal flux greater than $1 \mathrm{~kg} \cdot \mathrm{m}^{-1}$ in the rangeland, against 47 in the millet field, to be compared to 60 according to the measurements performed in the millet field (Abdourhamane Touré et al., 2011). In 2006, the largest event in the rangeland (July $5^{\text {th }}$ ) or the two largest events in the millet field (July $5^{\text {th }}$ and June $15^{\text {th }}$ ) contribute more than $50 \%$ in mass to the annual horizontal flux. Similarly, the strongest modeled event takes place on May $26^{\text {th }}$ for both surfaces in 2007, while in 2008 the simulation yields a strongest daily horizontal flux on July $4^{\text {th }}$ in the millet field and on May $20^{\text {th }}$ in the rangeland. This high horizontal flux on July $4^{\text {th }}$ corresponds to wind speed ranging between $10 \mathrm{~m} \cdot \mathrm{s}^{-1}$ and $18 \mathrm{~m} . \mathrm{s}^{-1}$ at $2.5 \mathrm{~m}$ height and lasting approximately 1 hour until the rain starts. For this event, the threshold friction velocity is much stronger in the rangeland (where the vegetation growth has already started) than in the millet field.

Each year, at least the two largest events simulated in the millet field are among the 5 largest measured horizontal fluxes. In other words, simulations are consistent with the dynamics of the main erosion events. The difference between horizontal flux from the rangeland and from the millet field is mainly due to the time shift between the two vegetation cover types (see Figure 4), which illustrates the high sensitivity of wind erosion to the vegetation dynamics at this period. 


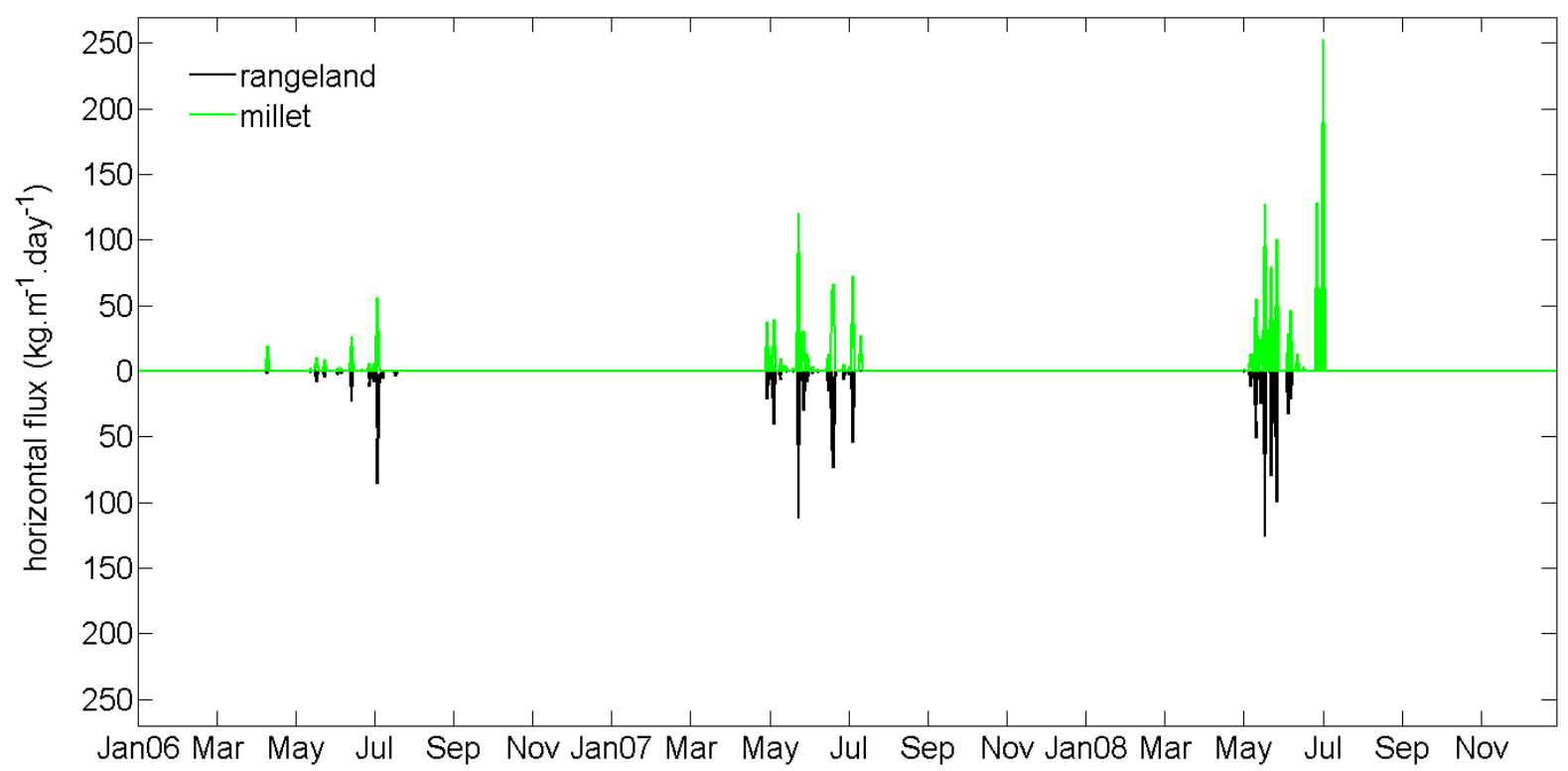

Figure 13: Simulated daily horizontal flux for the rangeland and the millet field at Banizoumbou from 2006 to 2008.

In terms of annual cumulated mass, the agreement between measured and modeled horizontal fluxes in the millet field is satisfying (Figure 13 and Table 3). The annual amounts increase through years, but the strong value simulated for the millet in 2008 is mainly due to the large event on July $4^{\text {th }}$. This simulated event is not caused by the underestimation of millet height at this period (Figure $5)$, since a simulation performed with larger millet heights yields an important event too: the horizontal flux is $226 \mathrm{~kg} \cdot \mathrm{m}^{-1}$ with a millet height of $0.35 \mathrm{~m}$ (taken from the measurements), compared to the original $253 \mathrm{~kg} \cdot \mathrm{m}^{-1}$ with a millet height of $0.20 \mathrm{~m}$ (parameterized from vegetation model outputs). Total horizontal fluxes in 2006 are sensibly lower than in the other years: strong winds (>10 m. $\mathrm{s}^{-1}$ ) are indeed less frequent in 2006 (0.08\%) than in 2007 and 2008 (0.11\% for both years). The total simulated horizontal flux from the millet field is higher than that from the rangeland over the 3year period. It is not the case in 2006, mainly because of the early start of millet growth, while the rangeland underwent a false-start and thus a delayed growth. In other words, the simulated horizontal flux from the millet field might be underestimated in 2006 because of an earlier start of millet growth in the simulations compared to the in situ measurements (Figure 5). Overall, phenology, especially in the early stages, as well as field management practices (including grazing) are important factors for wind erosion simulations in the Sahel, possibly more critical for erosion than for rangeland and cropland productivity modeling.

Table 3: Simulated horizontal fluxes $\left(\mathrm{kg}^{-1} \mathrm{~m}^{-1} \cdot \mathrm{yr}^{-1}\right)$ for the rangeland and the millet field at Banizoumbou from 2006 to 2008.

\begin{tabular}{|l|c|c|c|c|}
\hline & $\mathbf{2 0 0 6}$ & $\mathbf{2 0 0 7}$ & $\mathbf{2 0 0 8}$ & Total \\
\hline Millet field (measurements) & 269 & 576 & 619 & 1463 \\
\hline Millet field (simulations) & 154 & 527 & 885 & 1565 \\
\hline Rangeland (simulations) & 173 & 440 & 455 & 1069 \\
\hline
\end{tabular}




\section{Concluding remarks}

This study proposes a modeling approach to quantify and compare sediment horizontal fluxes from Sahelian croplands and rangelands, using two vegetation growth models and a wind erosion model. Cropping and pastoral practices have been taken into account, as well as the phenological differences between annual grass and millet. Simulation results reproduce satisfyingly the available measurements.

As a main result, the horizontal flux appears to be higher in croplands than in rangelands by approximately a factor 1.5 in mass, on average over 3 years. It suggests that land use and land use change may have an impact on Sahelian dust emissions, both because of the expansion of cropped land and because of evolving farming practices (e.g. collection of millet stover). The difference between the two surface types is mainly due to the delayed increase in vegetation mass of about 2 to 3 weeks in millet fields compared to annual grass in rangelands, and to a weaker soil surface protection in the cropped fields at the end of the dry season. The time shift between grass and millet is also partly due to the scattering of millet plants, which are sown in hills about a meter apart from each other, and to the weeding which is systematically carried out once or twice a year for millet fields. These practices result in a rather low vegetation mass (per surface unit) at the early stages of millet growth. This delay in vegetation growth occurs when (i) the surface is the least protected against wind erosion and (ii) high wind speeds are frequently recorded. The importance of the amount of dry vegetation (standing straws and litter laying down) at the end of the dry season for wind erosion was also pointed in Mongolian grasslands (Nandintsetseg and Shinoda, 2015), where the rainy season growth has a strong influence on the wind erosion occurring during the following dry season. As a consequence, cropping and pastoral practices and the changes thereof have played in the recent past, and could play in the future, a significant role in the changes in wind erosion for such surface types.

Althgough the simulations of vegetation and surface characteristics $\left(Z_{0}\right)$ proved to be in good agreement with field observations, there is room for improvement especially for the period when most of wind erosion occurs, i.e. the late dry season and the early rainy season (May-June). Indeed, dry vegetation then is critical but vegetation growth models where not originally designed to specifically simulate vegetation during this period. Modeling of straws, litter and crop residues disapearance rates in these models could be improved, particularly if specific measurements are carried out. Parameterizations of $Z_{0}$ could also be improved using more complete datasets, describing the contributions of litter and standing vegetation more precisely. Remote sensing might be helpful to quantify dry vegetation for regional studies (Kergoat et al., 2015).

Overall, there are reasons to think that the difference between millet fields and rangelands or fallows that are found in this study is on the lower edge of what can be found in the Sahel. First, accounting for woody plants, which is not done in these case studies, would probably reduce the simulated horizontal fluxes, particularly from rangelands and old fallows, where woody plants are more numerous. Indeed, several studies measured an almost negligible horizontal flux over fallows (Rajot, 2001; Bielders et al., 2004): the discrepancy with the present simulations might partly be due to the woody population. Second, the millet stems, in the present case studies, were not collected at harvest, in agreement with the local observations. However, there is a Sahel-wide tendency to use millet stems increasingly either for building or as fodder for livestock. Fields without residues are exposed to wind erosion much earlier during the dry season. Third, the Agoufou site supports a 
relatively high number of grazing animals, since it is close to a permanent pond. A significant part of the pastoral Sahel is probably less intensely grazed in the dry season, due to distance from water supply.

Alltogether, these statements imply that the difference between millet fields and rangelands may be higher in many places. There is a need to address these different issues, especially at a larger scale. The simulations are also sensitive to several physical parameters that are difficult to constrain, e.g. in the drag partition scheme (Pierre et al., 2014b). Thus, further studies focusing on the effects of Sahelian land use on wind erosion represent an interesting perspective to the present work.

\section{Acknowledgments}

This work has been supported by the research program CAVIARS (ANR-12-SENV-0007-01) from the French Agence Nationale de la Recherche. The authors thank the AMMA-CATCH observatory (African Monsoon Multidisciplinary Analysis/Couplage de l'Atmosphère Tropicale et du Cycle Hydrologique: www.amma-catch.org) for supporting the Agoufou field measurements. Solar radiation data at Banizoumbou were obtained from the Atmospheric Radiation Measurement (ARM) Program sponsored by the U.S. Department of Energy, Office of Science, Office of Biological and Environmental Research, Climate and Environmental Sciences Division. We also thank Manuela Grippa for providing updates of the STEP model, Mamadou Diawara for providing the Agoufou livestock observations and Nogmana Soumaguel for providing the vegetation measurements at Agoufou.

\section{Appendix}

Dry-season submodels have been developped for the STEP (Delon et al., 2015) and SarraH models (this study) in order to simulate the evolution over time of dry vegetation masses in response to biotic and abiotic factors.

For SarraH, the additional state variables are the masses of standing stems, standing leaves, stem litter and leaves litter. At harvest, standing stems and leaves are initialised from their 'green' equivalent (stems and leaves), which in turn are set to zero. According to a prescribed crop management scenario, all or parts of the stems and leaves can be taken out of the field. This corresponds to the increasing trend of collecting most of the crop residues, either stored as livestock fodder or used as construction material (fences, huts, thatch ...). In this study, all stems and leaves remain in the field as residues after harvest.

During the dry season, the standing masses decay because of herbivory, decomposition, and abrasion. In addition, they are converted to litter (of stem and of leaves), mostly by trampling but also because of wind. Litter is also subject to herbivory (including by livestock and termites), decomposition, and burrying by livestock trampling. Field preparation for the next crop season usually occurs in the late dry season. It consists in turning all standing residues into litter. Here the date of field clearing is set to January $1^{\text {st }}$.

A set of differential equations is used to simulate these different processes: 
$\frac{\partial B_{l e a v}^{\text {stand }}}{\partial t}=-\left(K_{3}^{\text {degra }}+K_{3}^{\text {tramp }}+K_{3}^{\text {ing }}\right) B_{\text {leav }}^{\text {stand }}$

$\frac{\partial B_{\text {stem }}^{\text {lit }}}{\partial t}=K_{1}^{\text {tramp }} B_{\text {stem }}^{\text {stand }}-K_{2} B_{\text {stem }}^{\text {lit }}$

$\frac{\partial B_{\text {leav }}^{\text {lit }}}{\partial t}=K_{3}^{\text {tramp }} B_{\text {leav }}^{\text {stand }}-K_{4} B_{\text {leav }}^{\text {lit }}$

The stem degradation coefficient $K_{1}^{\text {degra }}$ is set to $0.001\left(\mathrm{~d}^{-1}\right)$ and the trampling coefficient $K_{1}^{\text {tramp }}$ is set to $0.003 \times$ livestock $\left(\mathrm{d}^{-1}\right)$. Livestock density is expressed in Tropical Livestock Unit per $\mathrm{km}^{2}$. Similarly, for leaves, the degradation coefficient is set to $0.001\left(\mathrm{~d}^{-1}\right)$, the trampling coefficient is set to $0.003 \times$ livestok $\left(d^{-1}\right)$, and there is an additional feed intake coefficient set to $0.005 \times$ livestock $\left(d^{-1}\right)$. For stem litter, $K_{2}$ is the sum of a degradation coefficient set to $0.011\left(\mathrm{~d}^{-1}\right)$ and the same trampling coefficient as for standing stem. For leaves litter, $\mathrm{K}_{4}$ is the sum of a degradation coefficient also set to $0.011\left(\mathrm{~d}^{-1}\right)$, the same trampling coefficient as for standing leaves, and the same feed intake coefficient as for standing leaves.

The coefficients are derived to be consistent with field studies (Schlecht et al. 2001; Hiernaux and Ayantunde, 2004; Kergoat et al., 2015) and with the STEP model (Mougin et al., in prep.; Delon et al., 2015). The litter degradation coefficients are directly taken from Abdourahmane Toure et al. (2011). Given the scarcity of field data, the difficulty to infer experimental conditions like stocking rates from literature, the number of prescribed values was kept low, and taken as close as possible to the STEP values and Abdourahamane Toure et al. (2011) values.

The STEP model has a more detailed representation of processes, since it includes the effect of soil moisture on degradation, and the effect of different livestock species. Parameters were ajusted to match Agoufou dry season data, which benefits from livestock census and dry season mass measurements (Mougin et al., in prep; Delon et al., 2015; Diawara, 2015).

\section{References}

Abdourhamane Touré, A., J. L. Rajot, Z. Garba, B. Marticorena, C. Petit, and D. Sebag, 2011: Impact of very low crop residues cover on wind erosion in the Sahel, Catena, 85, 205-214, doi: 10.1016/j.catena.2011.01.002.

Bagnold, R.A., 1941: The physics of blown sand and desert dunes, Methuen, London, $265 \mathrm{pp}$.

Balme, M., T. Vischel, T. Lebel, C. Peugeot and S. Galle, 2006: Assessing the water balance in the Sahel: Impact of small scale rainfall variability on ruoff. Part 1: Rainfall variability analysis, J. Hydrol., 331, 336-348.

Baron, C., B. Sultan, M. Balme, B. Sarr, and S. B. Traoré, 2005: From GCM grid cell to agricultural plot: Scale issues affecting modelling of climate impact. Philos. Trans. R. Soc. B: Biol. Sci., 360, 2095-2108. 
Bielders, C.L., J.P.A Lamers, and K. Michels, 2001a: Wind erosion technologies in the West African Ann. Arid Zone, 40, 369-394.

Bielders, C.L., A. Vrieling, J.-L. Rajot, and E. Skidmore, 2001b: On-farm evaluation of field-scale soil losses by wind erosion under traditional management in the Sahel. In J.C. Ascough II and D.C. Flanagan (Eds). Soil erosion research for the 21st century, p. 494-497.

Bielders, C. L., J.-L. Rajot, and M. Amadou, 2002: Transport of soil and nutrients by wind in bush fallow land and traditionally managed cultivated fields in the Sahel, Geoderma 109, 19-39.

Bielders, C. L., J.-L. Rajot, and K. Michels, 2004: L'érosion éolienne dans le Sahel nigérien: influence des pratiques culturales actuelles et méthodes de lutte, Sécheresse, 15(1), 1-14.

Boucher, O., et al., 2013: Clouds and Aerosols, In: Climate Change 2013: The Physical Science Basis. Contribution of Working Group I to the $5^{\text {th }}$ Assessment Report of the IPCC, Cambridge Univ., Cambridge (UK), and New York (USA).

Boulain, N., B. Cappelaere, D. Ramier, H. B. A. Issoufou, O. Halilou, J. Seghieri, F. Guillemin, J. Gignoux, and F. Timouk, 2009: Towards an understanding of coupled physical and biological processes in the cultivated Sahel - 2. Vegetation and carbon dynamics, J. Hydrol. 375 (1-2), 190-203.

Breuning-Madsen, H., T.W. Awadzi, and G. Lyngsie, 2015: Deposition of Nutrients from Harmattan Dust in Ghana, West Africa, Pedosphere, 25(4), 613-621.

Chin, M., T. Diehl, Q. Tan, J. M. Prospero, R. A. Kahn, L. A. Remer, H. Yu, A. M. Sayer, H. Bian, I. V. Geogdzhayev, B. N. Holben, S. G. Howell, B. J. Huebert, N. C. Hsu, D. Kim, T. L. Kucsera, R. C. Levy, M. I. Mishchenko, X. Pan, P. K. Quinn, G. L. Schuster, D. G. Streets, S. A. Strode, O. Torres, and X.-P. Zhao, 2014: Multi-decadal aerosol variations from 1980 to 2009: a perspective from observations and a global model, Atmos. Chem. Phys., 14, 3657-3690, doi: 10.5194/acp-14-3657-2014.

Cowie, S., P. Knippertz, and J. Marsham, 2013: Are vegetation-related roughness changes the cause of the recent decrease in dust emission from Sahel?, Geophys. Res. Lett., 40, 1868-1872, doi:10.1002/grl.50273.

Dardel, C., L. Kergoat, P. Hiernaux, E. Mougin, M. Grippa, and C. J. Tucker, 2014: Re-greening Sahel: 30-years of remote sensing data and field observations (Mali, Niger), Remote Sens. Environ., 140, 350-364.

Deacon, E. L., 1953: Vertical profiles of the mean wind in the surface layers of the atmosphere, Geophys., Mem. 91, Meteorol. Off., H. M. Stationery Off., U.K.

Delon, C., E. Mougin, D. Serça, M. Grippa, P. Hiernaux, M. Diawara, C. Galy-Lacaux, and L. Kergoat, 2015: Modelling the effect of soil moisture and organic matter degradation on biogenic NO emissions from soils in Sahel rangeland (Mali), Biogeosciences, 12, 3253-3272.

De Rosnay, P., C. Gruhier, F. Timouk, F. Baup, E. Mougin, P. Hiernaux, L. Kergoat, and V. Le Dantec, 2009: Multi-scale soil moisture measurements at the Gourma meso-scale site in Mali, J. Hydrol., 375, 241-252. 
Diawara, M., 2015: Impact de la variabilité climatique au nord Sahel (Gourma) sur la dynamique des ressources pastorales et leurs conséquences sur les productions animales, 150 p., PhD thesis, Toulouse Univ.

Dingkuhn, M., C. Baron, V. Bonnal, F. Maraux, and B. Sarr, 2003: Decision Support Tools for Rainfed Crops in the Sahel at the Plot and Regional Scales. In A Practical Guide to Decision-Support Tools for Agricultural Productivity and Soil Fertility Enhancement in Sub-Saharan Africa, IFDC, CTA; StruifBontkes, T.E., Wopereis, M.C.S., Eds.; International Fertilizer Development Center: Muscle Shoals, AL, USA, pp. 127-139.

Doherty O.M., N. Riemer, and S. Hameed, 2014: Role of the convergence zone over West Africa in controlling Saharan mineral dust load and transport in the boreal summer, Tellus, B 2014, 66, 23191, doi: 10.3402/tellusb.v66.23191.

Fécan, F., B. Marticorena, and G. Bergametti, 1999: Parameterization of the increase of the aeolian erosion threshold wind friction velocity due to soil moisture for semiarid areas, Ann. Geophys., 17, 149-157.

Frappart F., P. Hiernaux, F. Guichard, E. Mougin, L. Kergoat, M. Arjounin, F. Lavenu, M. Koite, J.E. Paturel, and T. Lebel, 2009: Rainfall regime across the Sahel band in the Gourma region, Mali, J. Hydrol., 375 (1-2), 128-142, doi:10.1016/j.jhydrol.2009.03.007.

Fryrear, D. W., 1986: A field dust sampler, J. Soil Water Conserv., 41, 117-120.

Gillette, D. A., 1979: Environmental factors affecting dust emission by wind erosion, Saharan Dust, Ed. C. Morales, 71-94, John Winley, New York.

Guichard, F., L. Kergoat, E. Mougin, F. Baup, P. Hiernaux, and F. Lavenu, 2009: Surface thermodynamics and radiative budget in the Sahelian Gourma: Seasonal and diurnal cycles, J. Hydrol., 375(1-2), 161-177, doi:10.1016/j.jhydrol.2008.09.007.

Haywood, J. M. and O. Boucher, 2000: Estimates of the direct and indirect radiative forcing due to tropospheric aerosols: A review, Rev. Geophys., 38, 513-543.

Hermann L., R. Jahn, T. Maurer, 2010: Mineral dust around the Sahara, from source to sink. A review with emphasis on contributions of the German Soil Science Community in the last twenty years. J. Plant. Nutr. Soil Sci., 173, 811-821.

Hiernaux P., and A. Ayantunde, 2004: The Fakara: a semi-arid agro-ecosystem under stress. First phase (July 2002 - June 2004) of the DMP-GEF Program (GEF/2711-02-4516) ILRI, www.jircas.affrc.go.jp/project/africa_dojo/Metadata/grad_research/15.pdf

Hiernaux, P., and M. D. Turner, 2002: The influence of farmer and pastoralist management practices on desertification processes in the Sahel, in Global Desertification: Do Humans cause deserts?, Ed. J.F. Reynolds and D. M. Stafford Smith, Dahlem Univ. Press. , 135:148.

Ikazaki, K, H. Shinjo, U. Tanaka, S. Tobita, S. Funakawa and T. Kosaki, 2011: "Fallow Band system", a land management practice for controlling desertification and improving crop production in the Sahel, 
West Africa. 1. Effectiveness in desertification control and soil fertility improvement, Soil Sci. Plant Nutr., 57 (4), 573-586.

IPCC (Intergovernmental Panel on Climate Change), 2007: Climate Change 2007: The Physical Science Basis. Contribution of Working Group I to the Fourth Assessment Report of the IPCC.

Jarlan L., E. Mougin, P. L. Frison, P. Mazzega, and P. Hiernaux, 2002 : Analysis of ERS wind scatterometer time series over Sahel (Mali), Remote Sens. Environ., 81(2-3), 404-415.

Jickells, T. D., et al. (2005), Global iron connections between desert dust, ocean biogeochemistry, and climate, Science, 38(5718), 67-71, doi: 10.1126/science.1105959.

Kawamura, R., 1951: Study of sand movement by wind, Univ. Tokyo, Institute for Science and Technology, Report 5.

Kergoat, L., P. Hiernaux, C. Dardel, C. Pierre, F. Guichard, and A. Kalilou, 2015: Dry-season vegetation mass and cover fraction from SWIR1.6 and SWIR2.1 band ratio: Ground-radiometer and MODIS data in the Sahel, Int. J. Appl. Earth Obs. Geoinf., 39, 56-64, doi 10.1016/j.jag.2015.02.01

King, J., W. C. Nikling and J. A. Gillies, 2005: Representation of vegetation and other non erodible elements in Aeolian shear stress partitioning models for predicting transport threshold, J. Geophys. Res., 110, doi: 10.1029/2004JF000281.

Kouressy, M., M. Dingkuhn, M. Vaksmann, and A.B. Heinemann, 2008: Adaptation to diverse semiarid environments of sorghum genotypes having different plant type and sensitivity to photoperiod. Agric. For. Meteorol., 148, 357-371.

Lebel, T., and A. Ali, 2009: Recent trends in the Central and Western Sahel rainfall regime (19902007), J. Hydrol., 375, 52-64.

Levy, P.E., and P. G. Jarvis, 1999: Direct and indirect measurements of LAI in millet and fallow vegetation in HAPEX-Sahel, Agric. For. Meteorol., 97, 199-212.

Li, J., G. S. Okin, J. Tatarko, N. P. Webb, and J. E. Herrick, 2014: Consistency of wind erosion assessments across land use and land cover types: a critical analysis, Aeolian Res., 15, 253-260.

Lo Seen D., E. Mougin, S. Rambal, A. Gaston, and P. Hiernaux, 1995: A regional Sahelian grassland model to be coupled with multispectral satellite data. II. Towards the control of its simulations by remotely sensed indices, Remote Sens. Environ., 52, 194-206.

Lyles, L., and B. E. Allison, 1976: Wind erosion: the protective role of simulated standing stubble. Trans. ASAE, 19(I), 61-64.

Mahowald, N. M., G. D. Rivera Rivera, and C. Luo, 2004: Comment on "Relative importance of climate and landuse in determining present and future global soil dust emission" by I. Tegen et al., Geophys. Res. Lett., 31, L24105, doi: 10.1029/2004GL021272.

Mahowald, N.M., S. Kloster, S. Engelstaedter, J. K. Moore, S. Mukhopadhyay, J. R. McConnell, S. Albani, S. C. Doney, A. Bhattacharya, M. A. J. Curran, M. G. Flanner, F. M. Hoffman, D. M. Lawrence, 
K. Lindsay, P. A. Mayewski, J. Neff, D. Rothenberg, E. Thomas, P. E. Thornton, and C. S. Zender, 2010: Observed 20th century desert dust variability: impact on climate and biogeochemistry, Atmos. Chem. Phys., 10, 10875-10893, doi: 10.5194/acp-10-10875-2010.

Marteau, R., B. Sultan, V. Moron, A. Alhassane, and C. Baron, 2011: The onset of the rainy season and farmers' sowing strategy for pearl millet cultivation in Southwest Niger. Agric. For. Meteorol., 151, 1356-1369.

Marticorena, B., and G. Bergametti, 1995: Modeling the atmospheric dust cycle: 1. Design of a soil derived dust production scheme, J. Geophys. Res., 100, 16415-16430, doi: 10.1029/95JD00690.

Marticorena, B., M. Kardous, G. Bergametti, Y. Callot, P. Chazette, H. Khatteli, S. Le Hégarat-Mascle, M. Maillé, J-L. Rajot, D. Vidal-Madjar, and M. Zribi, 2006: Surface and aerodynamic roughness in arid and semi arid areas and their relation to radar backscatter coefficient, J. Geophys. Res., 111, F03017, doi: $10.1029 / 2006 J F 000462$.

Mougin, E., D. Lo Seen, S. Rambal, A. Gaston and P. Hiernaux, 1995: A regional Sahelian grassland model to be coupled with multispectral satellite data. I: Model description and validation, Remote Sens. Environ., 52, 181-193.

Mougin, E., P. Hiernaux, L. Kergoat, M. Grippa, P. de Rosnay, F. Timouk, V. Le Dantec, V. Demarez, F. Lavenu, M. Arjounin, T. Lebel, N. Soumaguel, E. Ceschia, B. Mougenot, F. Baup, F. Frappart, P.L. Frison, J. Gardelle, C. Gruhier, L. Jarlan, S. Mangiarotti, B. Sanou, Y. Tracol, F. Guichard, V. Trichon, L. Diarra, A. Soumaré, M. Koité, F. Dembélé, C. Lloyd, N.P. Hanan, C. Damesin, C. Delon, D. Serça, C. Galy-Lacaux, J. Seghieri, S. Becerra, H. Dia, F. Gangneron, and P. Mazzega, 2009: The AMMA Gourma observatory site in Mali: Relating climatic variations to changes in vegetation, surface hydrology, fluxes and natural resources, J. Hydrol., 375(1-2), 14-33, doi: 10.1016/ j.jhydrol.2009.06.045.

Mougin E., V. Demarez, M. Diawara, P. Hiernaux, N. Soumaguel, and A. Berg, 2014 : Estimation of LAI, fCover and fAPAR of Sahel rangelands (Gourma, Mali), Agric. For. Meteorol., 198-199, 155-167.

Mougin E., P. Hiernaux, M. Grippa, C. Delon, L. Kergoat, and V. Le Dantec, in prep.: Modelling seasonal and interannual vegetation dynamics in Sahel: a reconsideration of the STEP model.

Moulin, C., and I. Chiapello, 2006: Impact of human-induced desertification on the intensification of Sahel dust emission and export over the last decades, Geophys. Res. Lett., 33, L18808, doi: 10.1029/2006GL025923.

Mulitza, S., D. Heslop, D. Pittauerova, H.W. Fisher, I. Meyer, J-B. Stuut, M. Zabel, G. Mollenhauer, J.A. Collins, H. Juhnert and M. Schulz, 2010: Increase in African dust flux at the onset of commercial agriculture in the Sahel region, Nature, 466, doi: 10.1038/nature09213.

Nandinstetseg, B., and M. Shinoda, 2015: Land surface memory effects on dust emission in a Mongolian temperate grassland, J. Geophys. Res., doi: 10.1002/2014/JG002708.

Pasquill, F., 1950 : The aerodynamic drag of grassland, Proc. R. Soc., Ser. A., 202, 143-153. 
Pierre, C., G. Bergametti, B. Marticorena, E. Mougin, T. Lebel, and A. Ali, 2011: Pluriannual modeling, J. Geophys. Res., 116, D18201, doi: 10.1029/2011JD016115.

Pierre, C., G. Bergametti, B. Marticorena, E. Mougin, C. Bouet, and C. Schmechtig, 2012: Impact of vegetation and soil moisture seasonal dynamics on dust emissions over the Sahel, J. Geophys. Res., 117 (D6), doi: 10.1029/2011JD016950.

Pierre, C., G. Bergametti, B. Marticorena, A. Abdourhamane Touré, J-L. Rajot, and L. Kergoat, 2014a: Modeling wind erosion flux and its seasonality from a cultivated Sahelian surface: A case study in Niger, Catena, 122, 61-71, doi: 10.1016/j.catena.2014.06.006.

Pierre, C., G. Bergametti, B. Marticorena, L. Kergoat, E. Mougin, and P. Hiernaux, 2014b: Description of a heterogeneous vegetation cover and its drag partition for the estimation of dust emission, $J$. Geophys. Res., 119 (10), 2291-2313, doi: 10.1002/2014JF003177.

Priestley, C.H.B., 1959: Turbulent Transfer in the lower atmosphere, 130 pp., Univ. Chicago Press, Chicago.

Rajot, J.-L., 2001: Wind blown sediment mass budget of Sahelian village land units in Niger, Bull. Soc. Geol. Fr., 172, 523-531, doi: 10.2113/ 172.5.523.

Ridley D., C. Heald, and J. Prospero, 2014: What controls the recent changes in African mineral dust aerosol across the Atlantic? Atmos. Chem. Phys. Discus. 14(3), 3583-3627.

Rockstrom, J., and A. de Rouw, 1997: Water, nutrients, and slope position in on-farm pearl millet cultivation in the Sahel, Plant Soil, 195, 311-327.

Sabre, M., 1997: Etude dynamique du processus d'émission de poussières désertiques: impact sur le fractionnement physico-chimique entre sol et aérosol, PhD thesis, Paris VII Univ.

Saugier, B., and E. A. Ripley, 1978: Evaluation of the aerodynamic method of determining fluxes over natural grassland, Q. J. R. Meteorol. Soc., 104, 257-270.

Schlecht E., I. Kadaouré, F. Graef, C. Hülsebusch, F. Mahler and K. Becker, 2001: Agro-pastoral Farming Systems of Western Niger, Die Erde, 132: 399-418.

Schlecht, E., P. Hiernaux, F. Achard, and M. Turner, 2004: Livestock related nutrient budgets within village territories in western Niger, Nutr. Cycl. Agroecosys., 68, 199-211.

Siddoway, F.H., W.S. Chepil, and D.V. Armbrust, 1965: Effect of kind, amount, and placement of residue on wind erosion control, Trans. ASAE, 8(3), 327-331.

Stanelle, T., I. Bey, T. Raddatz, C. Reick, and I. Tegen, 2014: Anthropogenically induced changes in twentieth century mineral dust burden and the associated impact on radiative forcing, J. Geophys. Res. Atmos., 119, doi: 10.1002/2014JD022062.

Sterk, G., 2003: Causes, consequences and control of wind erosion in Sahelian Africa: a review, Land Degrad. Develop., 14, 95-108, doi: 10.1002/Idr.526. 
Swap, R., M. Garstang, S. Greco, R. Talbot and P. Källberg, 1992: Saharan dust in the Amazon Basin, Tellus, 44B, 133-149.

Tegen, I., and I. Fung, 1995: Contribution to the atmospheric mineral load from land surface modification, J. Geophys. Res., 100(D9), 18707-18726, doi: 10.1029/95JD02051.

Tegen, I., P. Hollrig, M. Chin, I. Fung, D., Jacob, and J. Penner, 1997: Contribution of different aerosol species to the global aerosol extinction optical thickness: Estimates from model results, J. Geophys. Res., 102, 23895-23915, DOI: 10.1029/97JD01864.

Tegen, I., M. Werner, S. P. Harrison, and K. E. Kohfeld, 2004: Relative importance of climate and landuse in determining present and future global soil dust emission, Geophys. Res. Lett., 31, L05105, doi: 10.1029/ 2003GL019216.

Tidjani, A. D., C. L. Bielders, and K. J-M. Ambouta, 2009: Dynamique saisonnière des paramètres déterminant l'érosion éolienne sur les pâturages dunaires du Niger oriental, Geo-Eco-Trop., 33, 3956 .

Tracol, Y., E. Mougin, P. Hiernaux, and L. Jarlan, 2006: Testing a Sahelian grassland functioning model against herbage mass measurements, Ecol. Model., 193, 437-446.

Traoré, S.B., A. Alhassane, B. Muller, M. Kouressy, and L. Somé, 2011: Characterizing and modeling the diversity of cropping situations under climatic constraints in west africa. Atmos. Sci. Lett., 12, 8995.

Velluet, C., J. Demarty, B. Cappelaere, I. Braud, H. B. A. Issoufou, N. Boulain, D. Ramier, I. Mainassara, G. Charvet, M. Boucher, J. P. Chazarin, M. Oï, H. Yahou, B. Maidaji, F. Arpin-Pont, N. Benarrosh, A. Mahamane, Y. Nazoumou, G. Favreau, and J. Seghieri, 2014: Building a field- and model-based climatology of local water and energy cycles in the cultivated Sahel - annual budgets and seasonality, Hydrol. Earth syst. Sci., 18, 5001-5024, doi: 10.5194/hess-18-5001-2014.

Walker, I. J., 2005: Physical and logistical considerations of using ultrasonic anemometers in aeolian sediment transport research, Geomorphology, 68(1), 57-76.

White, B.R., 1979: Soil transport by winds on Mars, J. Geophys. Res., 84, 4643- 4651. 